NBER WORKING PAPER SERIES

\title{
FINANCING DECISIONS AND PRODUCT INTRODUCTIONS OF PRIVATE AND PUBLICLY TRADED FIRMS
}

\author{
Gordon Phillips \\ Giorgo Sertsios \\ Working Paper 20578 \\ http://www.nber.org/papers/w20578 \\ NATIONAL BUREAU OF ECONOMIC RESEARCH \\ 1050 Massachusetts Avenue \\ Cambridge, MA 02138 \\ October 2014
}

We thank Nicholas Crain, Erik Gilje, Kathleen Kahle, Chen Lin, Jérôme Taillard, José Tessada, Patricio Valenzuela and seminar participants at Erasmus University, University of Amsterdam, University of Arizona, University of Southern California, Universidad Católica, the 2014 CICF conference, the 2014 FMA Asian Conference, the 4th mini-TOI conference and the 2nd Empirical Workshop in Management Science and Economics for helpful comments. We also thank Juan Cristobal Maass, MD-PhD, for helping us with medical institutional knowledge. We alone are responsible for any errors and omissions. Sertsios gratefully acknowledges the financial support of Fondecyt Iniciación (project/folio 11130073). The views expressed herein are those of the authors and do not necessarily reflect the views of the National Bureau of Economic Research.

NBER working papers are circulated for discussion and comment purposes. They have not been peerreviewed or been subject to the review by the NBER Board of Directors that accompanies official NBER publications.

(C) 2014 by Gordon Phillips and Giorgo Sertsios. All rights reserved. Short sections of text, not to exceed two paragraphs, may be quoted without explicit permission provided that full credit, including @ notice, is given to the source. 
Financing Decisions and Product Introductions of Private and Publicly Traded Firms

Gordon Phillips and Giorgo Sertsios

NBER Working Paper No. 20578

October 2014

JEL No. G3,G31,G32,L1,L22,L25,L26

\begin{abstract}
We exploit Medicare national coverage reimbursement approvals of medical devices as a quasi-natural experiment to investigate how private and publicly traded firm financing decisions and product introductions respond to exogenous changes in investment opportunities. We find that publicly traded companies increase their external financing, and their subsequent product introductions, by more than private companies in response to national coverage approvals. The primary source of the increased financing is through private financing of public firms. We also show that firms that select to go public during our sample period are ex ante more productive than similar private firms. The results are consistent with public firms bearing the costs of going public to gain financing advantages that come from being able to offer securities with better exit liquidity and lower price risk.
\end{abstract}

Gordon Phillips

Marshall School of Business, Hoffman Hall

University of Southern California

3670 Trousdale Parkway

Bridge Hall 308

Los Angeles, CA 90089-0804

and NBER

Gordon.Phillips@marshall.usc.edu

Giorgo Sertsios

Universidad de los Andes

School of Business and Economics

Las Condes, Santiago, Chile

gsertsios@uandes.cl 


\section{Introduction}

Choosing to be publicly traded has both potential costs and benefits. Costs include increased costs of disclosure of information, both direct and indirect, as well as potential increased agency problems arising from the separation of ownership and control. Offsetting these potential costs are the advantages to founders from obtaining liquidity and diversifying their wealth; and the ability to purchase other firms using IPO proceeds and liquid public stock. An additional large potential advantage of public firms is the ability to access additional external funds subsequent to improvements in investment opportunities. We investigate this potential new financing advantage of public firms by examining how private and public firms' financing decisions respond to exogenous changes in firms' investment opportunities.

We examine publicly traded and private firms in an ideal environment. We examine public and private firms' external financing decisions and product introductions in the medical device industry before and after Medicare approval of national coverage reimbursement for medical devices. The advantage of looking pre- and post-Medicare approval in a product category is that these events represent exogenous changes in the potential for investment and growth for both public and private firms operating in these product categories.

Our paper is the first to directly look at how publicly traded and privately held firms differ in the way they raise external financing when facing exogenous changes in their investment opportunities. In addition, we examine not only whether firms increase their external financing but also the type of funding — debt and equity — and the source of financing — private versus public markets. We also examine if there are differences in product introduction rates by public and private firms subsequent to the Medicare coverage decisions and firms' financing decisions

Previous papers examining publicly traded and privately held firms have focused on differences in investment decisions and have come to differing conclusions about whether it is advantageous for investment decisions for the firm to be publicly traded. Asker, Farre-Mensa and Lundquist (2013) using a large panel of matched public and private firms and Sheen (2009) in a sample of firms in the chemical industry find that public firms' investment decisions are less sensitive than private firms to investment opportunities. In contrast, Gilje and Taillard (2013) and Maksimovic, 
Phillips and Yang (2013) conclude that investment and merger decisions by public firms are more sensitive to changes in investment opportunities when using exogenous shocks to these firms and controlling for differential firm productivity. Gilje and Taillard (2013), in particular, use a natural experiment in the natural gas industry and provide evidence that publicly traded firms have higher investment sensitivity to investment opportunities than private firms. However, the exact source of differential investment sensitivity is unknown. This motivates our approach of directly examining public versus private financing decisions, and subsequent product introductions, following exogenous shocks to their investment opportunities.

There are two potential channels through which publicly traded firms may have an advantage relative to private firms in raising external financing. First, publicly traded firms have a broader access to external financing: they can issue seasoned equity and may be able to more easily issue corporate bonds - in addition to obtaining funds through privately placed equity or bank debt, as privately held firms. Second, publicly traded firms may have an advantage over privately held firms even in issuing private security placements to investors. These private security placements by public firms are called private investment in public equity (PIPEs). Through these securities, publicly traded firms can offer better exit liquidity and lower price risk to private investors relative to what investors can obtain by investing in private securities issued by private firms. In particular, private investors may prefer to invest in publicly traded firms through these private placements as they can liquidate their positions more easily, as public firms usually register these securities within one year. Along with this near term registration, private investors can effectively exit their positions by hedging them, even before the securities are registered: they can short sell the regular public equity in the public markets after the private security issuance is disclosed through a SEC filing. This hedging strategy reduces the price risk of holding the private securities.

Despite these potential advantages, it is possible that publicly traded firms may respond less to better investment opportunities - and thus be unable to capitalize on their potential financing advantages - due to agency considerations or a short-term focus of managers as has been postulated by Sheen (2009) and Asker, Farre-Mensa, and Lundquist (2013). Moreover, even if agency problems or short-term focus of managers were unimportant, it is still possible that publicly traded firms may not be able to capitalize on having access to public markets, as issuing in the 
public markets involves the disclosure of sensitive information as has been highlighted by Ali, Klasa and Yeung (2014) and Farre-Mensa (2011). Hence, understanding how publicly traded and privately held firms differ in their external financing sensitivities to investment opportunities is central to understand the advantages and disadvantages of each ownership structure.

The medical device industry is an ideal setting to test for the differences in external financing sensitivities to investment opportunities for several reasons. First, and most importantly, it is possible to identify an exogenous measure of changes to firms' investment opportunities. In the medical device industry, an exogenous demand shock occurs when Medicare approves national coverage decisions (NCD) for some devices, increasing the demand for devices in a given product line. Second, the scale of operation of most private and public companies is small, with approximately $75 \%$ of them specializing in a single product category. Using single segment firms is important, as we can isolate external financing transactions from within-firm lending through internal capital markets. Third, this industry traditionally has relied heavily on external financing and the lifecycle of products is much shorter than in other similar medical industries (e.g. the pharmaceutical and biotechnology industries). As a consequence, small companies typically do not require the financial backing of large corporations to develop their products. Firms' financing comes almost exclusively from financial institutions or private groups of investors.

We construct our dataset by combining several data sources. From the FDA website, we identify medical device companies that have received FDA approval to introduce or modify any medical device, during 1998-2010. From this data source, we can also identify the line of business in which medical device company operates, thus identifying whether the companies are affected by a NCD decision. We hand match the company information from the FDA with firms' security issuances and bank loans from Capital IQ and Deal Scan, identifying both private and public companies.

We find that private firms use less external financing than publicly traded firms. More importantly, we find that privately held companies increase their external financing by less than public traded companies when facing a NCD decision that applies to their product line. This result is robust to the inclusion of variables that control for firm size; to different matching procedures; and to the inclusion of firm fixed-effects. 
Interestingly, the increased probability of a public firm raising financing through a seasoned equity offering (SEO) is lower than that of a private firm raising financing through venture capital (VC) after a NCD. What drives the higher responsiveness of financing decisions of publicly traded firms is a sharp increase in public firms' issuance of private investments in public equity (PIPEs). The probability that a public firm raises funds through a PIPE transaction in a given year increases from 11.6 percent to 14.5 percent, a percentage increase of 25 percent. PIPE securities offer better exit liquidity than private placements in private firms, as these securities are typically registered with the SEC within six months to one year following their purchase, allowing private investors to sell them at this point. PIPE securities also offer lower price risk than private placements in private firms, as private investors can hedge their risk in these securities by selling the public equity short prior to the securities being registered (see Brophy, Ouimet and Sialm (2009)). Thus investments in the form of VC and PE in privately held companies are much riskier and relatively more difficult to liquidate than PIPEs, making the private securities issued by public firms more attractive to investors that value liquidity and wish to minimize price risk.

We show that the increased ability to raise external capital of public firms has a positive product market impact. We find that publicly traded firms operating in product categories that received a NCD approval during the sample period increase their product introduction rate by more than publicly traded firms not affected by NCDs, after the NCD approvals. Importantly, this difference is remarkably more pronounced than the difference in product introduction rates observed for private firms - affected and not affected by NCD approvals. These results are consistent with publicly traded firms being able to capitalize on their financing advantage and investing more in the development of new products. This evidence complements the results by Gilje and Taillard (2013) who show that publicly traded firms have a higher investment sensitivity to investment opportunities than private firms. We extend their work and show directly how the financing channel affects public firms' ability to respond to the increase in investment opportunities.

Lastly, we examine whether publicly traded firms' financing advantage causes firms to choose their organizational type based on their investment opportunities. Offsetting the financing advantage, being publicly traded is costly (underwriter fees, underpricing, information disclosure costs, separation of ownership and control). Thus, only those firms that benefit enough from the 
financing advantage of being publicly traded - firms with higher returns to investment opportunities — should choose to be publicly traded. We provide two pieces of evidence consistent this self-selection logic. First, we document that the firms that select to become public during our sample period introduce more products prior to their IPO than a sample of private firms of the same age that choose to stay private. ${ }^{1}$ Related to this, we also find that publicly traded firms without NCD approvals have a higher product introduction rate than privately held firms without NCD approvals. Note that these differences in pre-NCD product introductions do not explain the differential impact of NCDs on product introductions for private and public firms but do help indicate that firms with better investment opportunities choose to go public to gain financing advantages. We also find that publicly traded firms have higher sales per employee than private firms of the same age. Overall, our results are consistent with firms with higher returns to investment opportunities choosing to be public in order to take advantage of lower cost financing and more financing options available when good opportunities arise.

We contribute to the literature by being the first paper to look at the differential financing patterns by public and private firms in response to changes in exogenous investment opportunities. Previous papers have showed different financing frequencies by public and private firms, but not whether they react differently to changes in investment opportunities. Consistent with Brav (2009), our results show that private firms obtain external financing much less frequently than public firms. Importantly, we show that after controlling for the higher frequency in external financing that comes with the public status, publicly traded firms also respond differentially more to investment opportunities than private firms. This highlights a key advantage of being public: there is an option value in terms of an improved ability to respond more to investment opportunities.

Our paper shows that being publicly traded facilitates access to external financing when controlling for exogenous changes to investment opportunities, even in an industry where disclosure costs are potentially high for competitive reasons. This result may be viewed as surprising given that Farre-

\footnotetext{
${ }^{1}$ When documenting the financing advantage we control (or match) by products introduced per year, among other dimensions that may correlate with a firm's productivity. Studying differences in products per year for public and private firms matched only on their age is useful to understand firms' selection to be publicly traded, given the financing advantage that comes with the publicly traded status.
} 
Mensa (2011) concludes that in industries in which disclosure costs are high, access to public markets may not necessarily lead to an improvement in a firm's financing perspectives. Thus we contribute to the literature by showing that there is also a financing advantage for informationsensitive publicly traded firms, which comes from a more subtle channel. The public firms' financing advantage does not come directly through their ability to issue public equity, but rather through their ability to issue private securities which can be later converted into public securities and can be hedged in the public market. Public firms are able to share private information selectively to these private investors under an important exception to regulation Fair Disclosure (reg FD).

In a broader context, this paper contributes to the emerging literature that compares privately held and publicly traded firms. In addition to the papers that examine investment differences between public and private firms, Gao and Li (2013) examines differences in CEO pay, Gao, Harford and Li (2013) and Farre-Mensa $(2011,2014)$ examine differences in cash holdings; Michaely and Roberts (2012) examines differences in dividend policy; Saunders and Steffens (2011) examines differences in loan spreads; and Bernstein (2012) examines differences in innovative behavior for public firms versus private firms after public firms' initial public offerings.

The rest of the paper is organized as follows. Section II provides background on the medical device industry and Medicare national coverage decisions (NCD). Section III describes the data. Section IV lays out the empirical methodology. Section V presents the results on financing. Section VI presents the results on product introductions. Section VII discusses the selection of firms into public status. Section VIII concludes.

\section{Background on the Medical Device Industry}

The medical device industry covers a wide spectrum of products used in the treatment of patients, including cardiovascular devices, dental equipment, ophthalmic devices, orthopedic devices, respiratory devices, surgical equipment, among others. In 2012, this industry had sales of about $\$ 350$ billion worldwide, with U.S. manufacturers generating $40 \%$ of the revenue, and U.S. consumers representing about $30 \%$ of the global expenditure in these devices. 
From a public opinion perspective (and also from a research perspective), this industry has been overshadowed by the pharmaceutical industry, in spite of not being substantially smaller (its relative size is almost $50 \%$ in terms of revenues). Only recently this industry started to receive substantial attention by the press, as effective January $1^{\text {st }}, 2013$, a $2.3 \%$ excise tax on medical devices got into effect, as part of a plan to finance the Affordable Care Act.

The medical device industry has several features that make it an ideal setting to study the differences in financing patterns between privately held and publicly listed firms. First, this industry traditionally has had a low level of industry concentration, with no one firm dominating the industry (see Holtzman 2012). Small private and public companies are common, and most of them (approximately 75\%) specialize in a single product category. Having a large fraction of specialized companies is desirable from the perspective of this study, as internal capital markets considerations are not relevant, thus making it a cleaner setting to study external financing decisions.

Second, while this industry does rely on external financing to develop its products, the product lifecycle is much shorter than in other similar industries (e.g. pharmaceutical industry). Thus, companies do not typically require the financial backing of large corporations to develop their products. As a consequence, their financing comes almost exclusively from financial institutions and investors, and not from strategic partners.

\section{A. Regulation in the Medical Device Industry}

In the U.S., medical devices are regulated by the Food and Drug Administration (FDA). The FDA has two review processes. For medical devices that are classified as high risk, a pre-market approval process is required (PMA). This route involves the submission of manufacturing information, preclinical studies and clinical investigations (large randomized studies, as in the pharmaceutical industry, are not usually required). For medium risk devices, the FDA typically asks for a $510(\mathrm{k})$ submission. In this process, the manufacturer only needs to prove that the device is substantially equivalent to an existing device, in terms of safeness and effectiveness. This process is much shorter than the PMA review, taking less than a year. Importantly, the devices under this new modality need to be different to the existing devices in some respects (e.g., more 
accurate, faster, etc.), to avoid violating patent law. ${ }^{2}$ However, if a medium risk device is not substantially equivalent to an existing device that undergoes the $510(\mathrm{k})$ process, the PMA process applies.

Approximately 23\% of the FDA devices approved are under the PMA modality and 77\% under the $510(\mathrm{k})$ modality. Some low risk devices are exempt from FDA reviews (e.g. a tongue depressor).

\section{B. The Role of Medicare in the Medical Device Industry}

The bulk of the demand for medical devices in the U.S. comes from the elderly population. Medicare plays a crucial role in how this population is served. Medicare provides nearly universal public health insurance for elderly people (65 years or older), covering about $97 \%$ of the elderly population in the U.S. ${ }^{3}$

Medicare is composed of 4 parts: Parts A to D. The program started in 1965 offering only Part A. Part A covers hospital and impatient services. Part B covers outpatient services, including durable medical device expenses. Part $\mathrm{C}$ allows individuals to receive Medicare benefits through a private plan; and Part D — which recently entered into effect in 2006 - provides prescription drug coverage. In 2010, the program spending was $\$ 524$ billion, representing approximately 20 percent of total health expenditures, and 3.5 percent of the U.S. Gross Domestic Product (GDP).

Medicare pays for services by reimbursing health providers. Typically, Medicare sets in advance the prospective payments amounts that health providers will receive for services provided to Medicare enrollees. ${ }^{4}$ After service is provided, Medicare's fiscal agents pay the health providers the predetermined rates minus the beneficiaries' cost-sharing liabilities. For Medicare Part B the cost-sharing liability consists of a small deductible and a $20 \%$ co-payment (see Finkelstein and McKnight 2008). ${ }^{5}$ About 50\% of Medicare beneficiaries complement their coverage with other

\footnotetext{
${ }^{2}$ See, for example, Sunrise Medical HHG Inc. v. AirSep Corp.

${ }^{3}$ To be eligible individuals or their spouses need to have worked 40 quarters or more in covered employment.

${ }^{4}$ These payments differ by region, as costs of service might vary with geographic location.

${ }^{5}$ There is no uniform reimbursement procedure for medical devices. The cost of some devices is reimbursed within a medical procedure, while other devices are reimbursed independently. See How Medicare Pays for Services: an Overview, http://www.medpac.gov/publications/congressional_reports/mar02_ch1.pdf
} 
insurances, such as Medigap or health insurance programs provided by their employers (see Card et al. 2008).

\section{Medicare Coverage Decisions}

The Centers for Medicare and Medicare Services (CMS) chooses to make national coverage decisions (NCD) only when there is a major expected impact in the program, or there are cost, quality and safety concerns (see Neumann et al 2008; and Tunis et al. 2011). There are 3 NCDs categories: Medical Devices, laboratory/diagnostic tests and medical procedures. Examples of NCDs that have attracted general attention include the approval of the lung-volume reduction surgery - a medical procedure - and the approval of coverage for additional uses of implantable cardioverter defibrillators — a medical device — (see Gillik 2004).

The request of a national coverage decision can be generated internally by the CMS, or externally by interested parties such medical associations. ${ }^{6}$ A NCD approval is arguably an exogenous shock to a firm's investment opportunities as only in two cases the NCD decisions were initially proposed by very large medical device companies. These large firms are not in our sample, as we restrict our sample - as described in the data section - to companies that operate in a single product category with annual sales under $\$ 300$ million.

The approval rate after these requests for national coverage is about $60 \%$, and is similar for externally and internally generated requests (see Neumann et al 2008). The CMS's statutory directive is to pay for items and services that are "reasonable and necessary." However, what constitutes "reasonable and necessary" has not been clearly defined (Chambers et al 2012) and the CMS has commented that cost-effectiveness is not a factor in their NCD decisions. Overall, there is consensus among practitioners and experts that there is no clear understanding of what constitutes a good candidate for national coverage approval (see Foote 2002), making the outcome of NCD request very unpredictable.

Regarding medical devices, NCD approvals can take two forms: initial coverage of a device for certain medical uses, or the extension of coverage for additional uses of a previously approved

\footnotetext{
${ }^{6}$ See http://www.cms.gov/Center/Special-Topic/Medicare-Coverage-Center.html for an overview of the Medicare national coverage decision process and the Medicare coverage database.
} 
device. The approved devices almost invariably need to be FDA approved. ${ }^{7}$ The NCD approval for a given device is not limited to a particular manufacturer, but applies to the device itself. All modified versions of a Medicare approved device are covered, conditional on them being approved by the FDA.

Information about $\mathrm{NCD}$ can be found in the CMS' website. In the medical device category (i.e., durable medical equipment and prosthetic devices), between 1998 and 2010, the CMS issued 17 NCD approvals for 12 devices. ${ }^{8}$ There are more approvals than devices, as some devices where subsequently approved for additional uses during the sample period. Table 1 summarizes CMS's NCD approvals for 1998-2010. Column 1 shows the FDA product category of each device. Column 2 shows the name of the device that obtained national coverage approval. Column 3 shows the year in the sample period in which the device was first approved - or the first year in the sample period the device was granted extended coverage if some initial coverage was approved before 1998. Columns 4 and 5 show the year in which some of the devices obtained extended coverage during the sample period. Column 6 shows the year in which the device was initially approved, in case the initial approval was prior 1998. Column 7 shows the review process under which manufacturers need to submit their applications to get FDA approval on each device. Table 1, Panel B, shows the product categories that did not receive any NCD approval/extension during the sample period (1998-2010) that we use as our control group.

\section{Table 1 here}

To further clarify the content of Table 1, we describe the NCD approval process for two devices: the Implantable Automatic Defibrillators (IAD) and the Neuromuscular Electrical Stimulation (NMES). The history of NCDs for IAD is fairly long. IAD is an electronic device which was initially designed to detect and treat life-threatening tachyarrhythmia. For its use, it needs to be implanted in the patient. In 1986, CMS approved its coverage as last resort for patients who have had a documented episode of life-threatening ventricular tachyarrhythmia or cardiac arrest not

\footnotetext{
${ }^{7}$ Although not a NCD, an exception of CMS' policy of covering only FDA approved devices was CMS's resolution to give higher coverage to drug-eluting stents (DES) than to regular stents, prior to the FDA approval of DES. See http://www.theheart.org/article/198579.do

${ }^{8}$ This number does not include NCD approvals of medical devices for their exclusive use on medical trials ( 2 cases).
} 
associated with myocardial infarction. Effective in 1999, the CMS extended coverage for patients with a documented episode of cardiac arrest due to ventricular fibrillation not due to a transient or reversible cause; with ventricular tachyarrhythmia, either spontaneous or induced, not due to a transient or reversible cause; or with familial or inherited conditions with a high risk or lifethreatening ventricular tachyarrhythmia such as long QT syndrome or hypertrophic cardiomyopathy. In 2003, the CMS approved extended coverage for coronary artery disease with a prior myocardial infraction, sustained ventricular tachyarrhythmia and other technical specifications. In 2004, the CMS relaxed the technical conditions specified in 2003 and further extend the coverage for this device. The CMS's NCD approval of NMES, on the other hand, is much shorter. NMES involves the use of a device which transmits an electrical impulse to the skin over selected muscle groups by way of electrodes. In 2002, the CMS approved its use for the treatment of spinal cord injuries for patients to aid in walking.

A NCD in a product category acts effectively as a positive shock to the investment opportunities of firms operating in that product category. There are several channels through which this shock can affect firms. First, and more directly, some manufacturers might be producing the approved device at the time of the NCD. Thus, the demand for their devices may improve. Second, even if a manufacturer specialized in a product category (e.g. neurology devices) might not be producing the approved device at the time of the NCD (e.g., deep brain stimulation devices), it is typically the case that the technology it produces is sufficiently related that it can take advantage of the improved investment opportunities to develop the approved device. Third, the increased demand for a particular device may also increase the demand for other related devices in the same category. For example, the increased demand for CPAP machines (anesthesiology devices) also increased the demand for CPAP humidifiers, CPAP gauge manometers for pressure measurement, CPAP hoses, etc.

In Table 1, Panel C, we present evidence on an event study of NCD approvals on public firms' returns. We provide this evidence to establish that these events are of large consequence for the firms in this industry. We look at CARs for publicly traded firms operating in product categories affected by NCDs, for different windows surrounding the day when Medicare posts the memorandum with the approval decision. For an event window between -90 to +90 trading days 
from the memo release, firms display a $21 \%$ CAR, on average (statistically significant at the 5\% level). For narrower windows, the CAR is smaller. This is to be expected, as the NCD approval memo is usually preceded by a proposed decision memo, days or months prior to the final decision memo. Also, the real implications for medical device manufacturers are not entirely clear until a few days, or months, after the memo is released. All in all, the evidence presented in Panel C shows that NCD are of large economic relevance for firms affected by them.

\section{Data}

We construct our data using four data sources: the Food and Drug Administration (FDA) website, Capital IQ, Hoovers, and DealScan. Matching firms from these data sources is challenging, as there is no common identifier. Moreover, many companies within the medical device industry have very similar names, making any matching algorithm unviable. Thus, we manually match all datasets using the firms' names and addresses.

From the FDA website we collect information on all companies that have obtained FDA permission to introduce or modify a medical device for use in the United States from 1998 to 2010. We restrict the sample to start in 1998 as we merge this data with Capital IQ transaction data, and 1998 is the first year Capital IQ reports this data. In particular, from the FDA website, we obtain the companies' names and the number of approved product introductions and modifications per year (through the PMA and 510(k) processes). The FDA classifies medical devices into 19 categories (see Table 1, above). Using these categories we can identify the product line(s) of the medical device companies. We restrict our sample to those companies that operate in single product category. We do so, to isolate effect of the NCD approvals - which are product category specific - on firms' financing decisions. From Capital IQ we obtain firms' fund raising transactions, such as SEO, fixed-income offerings, PIPEs, VC, etc. From DealScan we obtain information on bank loans. ${ }^{9}$

\footnotetext{
${ }^{9}$ We compare Capital IQ deal coverage with other commonly used datasets, such as Venture Expert and SDC. Capital IQ is as comprehensive as these other databases, with the advantage of containing information on all type of deals except bank loans - in a single platform. DealScan is the most comprehensive database on bank loans.
} 
Ideally, we would like to have information on a firm's assets or sales on a yearly basis to control for the correlation between firms' size and external financing transactions. Unfortunately, that information is not available for private firms. ${ }^{10}$ However, Hoovers and Capital IQ contain information for firms' last year sales, both for private and public companies. Thus we use firms' last year sales as proxy for firm size - in addition to the number of products introduced per year obtained from the FDA website. We exclude companies with missing sales data.

Firms' need for external financing may also correlate with their age. Typically, older firms are more capable of using internal funds to invest, while younger firms depend more on external financing. To control for age we obtain information on firms' founding years from Capital IQ.

From Capital IQ, we can also identify whether a firm is a stand-alone company or a subsidiary. We restrict our sample to U.S. firms that are not operating subsidiaries of other companies, as it is central to our study to isolate external financing activities from internal capital market considerations. We also limit our sample to companies with sales of no more than US\$300 million, for two reasons. First, large public companies are typically not comparable to our sample of private companies. Second, large public companies may lobby for the approval of NCD decisions raising concerns about the exogeneity of NCD approvals on those large firms' external financing transactions. We exclude 54 firms with more than $\$ 300$ million in sales given this criteria. ${ }^{11}$

Our final data set is an unbalanced panel containing 19,217 firm-year observations for 1,820 companies. Of these, 17,916 observations belonging to 1,721 firms correspond to private firms, and 1,301 observations belonging to 119 firms correspond to publicly traded companies. ${ }^{12}$ The panel is unbalanced for two reasons. First, 727 companies were founded during our sample period. Second, 230 companies were acquired as subsidiaries by larger firms prior to the end of the sample period. As we do not consider operating subsidiaries in our sample, we drop the acquired company

\footnotetext{
${ }^{10}$ For a small fraction of private companies (SEC-filing private firms), Capital IQ provides short time series of historical financial data (see Gao and Li (2013) and Gao, Harford and Li (2013)). For the vast majority of the companies in our data this information is not available.

${ }^{11}$ Our results hold if we allow for less stringent cutoffs, e.g. \$500 million, \$1000 million, etc. However, introducing larger companies in the sample raises identification concerns, as large companies are more likely to participate in lobbying activities.

${ }^{12}$ The sum of private and public companies is higher than the total, as there a few companies that changed their listing status during the sample period.
} 
observations after the acquisition. For these companies, the reported sales consist of the division that the company represents in the parent company.

\section{A. Summary Statistics}

Table 2 provides the summary statistics of our sample. External Financing Amount represents the yearly amount of external financing raised by the companies in our sample. If a company does not raise funds externally in a year, this variable takes a value of 0 ; if it does, it takes the transaction amount. External Financing Transaction is an indicator variable that takes a value of 1 if a firm obtains external financing in a year, and 0 otherwise. The variable Private is an indicator variable which takes a value of 0 if a company was publicly listed in a year, and 1 otherwise. The variable NCD Approval takes a value of 0 if a company operates in a line of products that not received a NCD approval during the sample period, or in the years prior to a NCD approval. This variable increases by one if in its product line it receives a NCD approval or extension. For example, if a company operates in the radiology medical device business, NCD Approval takes a value of 0 during the whole sample, as there was no NCD in that product category. In contrast if a company operates in the cardiovascular medical device business, NCD Approval takes a value of 0 in 1998, it increases to 1 in 1999 after CMS approval for extended coverage for the Implantable Automatic Defibrillators, and ends up taking a value of 5 in 2010 as there were 5 NCD approvals/extensions for cardiovascular devices between 1998 and 2010.

\section{Table 2 here}

Products per year shows for each firm-year the number of FDA approved new products and approved modifications to existing products. This variable can be used as a time-variant measure of a firm's size, as companies that introduce more new products or propose more modified versions of existing products are also larger. The variable Age is the year of operations minus the founding year, and Sales represent the 2011 sales of a company in millions of dollars.

\section{B. External Financing Transactions}

Table 3, Panel A, shows the transaction types and average dollar value per transaction for the subsample of privately held companies. Venture capital transactions are the most common source of external financing for private companies, representing $68 \%$ of the deals. Private equity 
investments, sometimes referred to as growth capital, are the second most frequent used source of external financing for privately held firms, representing $23 \%$ of the deals. Bank loans and IPO transactions are observed less frequently. ${ }^{13}$ Only 22 firms of the sample of 1,721 private companies underwent an IPO during our sample period. Although the IPO transaction is initiated when a firm is privately held, the funds are received by the firm only when it changes its ownership status to publicly traded. Thus, we designate the amount raised through an IPO - and the transaction itself - to the year in which the firm becomes publicly traded and classify this transaction as one by a public company. However, our results are not sensitive to this classification. ${ }^{14}$

\section{Table 3 here}

Table 3, Panel B, shows the transaction types and average dollar value per transactions for the subsample of publicly traded companies. Private investments in public equity (PIPEs) are the most common source of external financing for publicly traded companies in our sample, representing $65 \%$ of the transactions. The fact that around $80 \%$ of the non-debt transactions (148 out of 185) are done through private markets relates to the small size of public firms in our sample (the mean size of sales is US $\$ 13$ million), but it is not unique to this industry. Using a sample that contains all industries, Gomes and Phillips (2012) find that among small public firms, 73\% of the non-debt issuances (equity and convertibles) are in the private markets. ${ }^{15}$

Relative to offerings in public markets, private offerings have the advantage that the issuer can provide new selective information to investors. Securities disclosure laws, including Regulation $F D$, exempt communications by the firm from the disclosure restrictions when those communications are to investors who "have expressly agreed to maintain the communication in confidence pursuant to a confidentiality agreement" (Houston and Laitin 2000). New information can be learned by investors if they have one-on-one meetings with the issuer's managers and

\footnotetext{
${ }^{13}$ Bank loans - and other forms of debt financing - are not observed very often in this in industry, given that investments in medical devices are generally non-collateralizable.

${ }^{14}$ Our results hold even if we classify the money raised as obtained by privately held firms (i.e., if the indicator variable Private takes a value of 1 , instead of 0 , during the IPO year). In other words, the way we define the ownership status during the IPO year does not drive the results.

${ }^{15}$ The fact that the fraction of private issuances in the medical decide industry is slightly larger than the average across all industries is most likely due to the high costs of disclosing information, which we postulate is for competitive reasons.
} 
employees and/or visit the issuer's facilities. The process holds both for private firms and for public firms selling private securities through PIPEs. ${ }^{16}$ Moreover, given the concentrated stakes taken by some investors in private placements, issuers have more incentives to expend effort into producing valuable information. Investors are likely to invest in industries in which they have expertise and thus are more able to process and interpret the information gathered during the due diligence process.

Despite these similarities of private securities issued by public and private firms, there are important advantages of private securities issued by publicly traded firms (PIPEs) over private securities by private companies. First, PIPE securities are much more liquid than private securities, as they are typically registered with the SEC within six to twelve months, allowing private investors to sell these securities in the regular public markets once they have become registered. The securities also contain "piggyback" registration rights that require the company to register the securities before selling any other stock and can contain penalties in the form of additional stock (payment in kind (PIK)) given to the investors if the company fails to register the equity with the SEC within a given period (see, for example, the PIPE issuance of World Heart Corp, Jan 2010). ${ }^{17}$

Once registered, the stock becomes identical to regular publicly traded equity and can be sold in the public market.

The second main advantage of PIPE securities is that prior to these securities being registered, private investors can also hedge the price risk in these securities. Investors can sell short the publicly traded equity, prior to the securities being registered, after the details of the securities have been disclosed to the public through an SEC filing such as an 8K or 13D. Brophy, Ouimet

\footnotetext{
${ }^{16}$ The informational advantage of PIPE securities, relative to public offerings made by public firms, is documented in Gomes and Phillips (2012). Another advantage for public issuers of issuing privately is that the transaction is faster to implement (see Chaplisnksy and Hausenhalter, 2010). The benefits of issuing privately (i.e., selective release of information and shorter issuance time) have to be trade-off against the price discount at which PIPEs are issued, relative to SEOs.

${ }^{17}$ The PIPE terms can be found in documents filed with the SEC. For example, in an 8k form (Jan 26 $\left.6^{\text {th }}, 2010\right)$, World Heart Corp commits to file the registration for the securities within 60 days of the issuance date: http://www.sec.gov/Archives/edgar/data/1024520/000110465910003065/a10-2442 18k.htm In the correspondent 13D schedule - Item 6 - they mention piggy-back registration rights: http://www.sec.gov/Archives/edgar/data/1024520/000119312510022178/dsc13da.htm
} 
and Sialm (2009) show that short selling is significant in the public equity of a firm after that firm has issued a PIPE security.

Overall, PIPE investments may thus be relatively more attractive to private investors who value liquidity than investments in the form of $\mathrm{VC}$ and $\mathrm{PE}$ in privately held companies, as they offer better exit liquidity and lower price risk to investors.

\section{Univariate Analysis}

In Table 4, Panel A, we compare the variable means for privately held and publicly traded companies. The table shows some differences between private and public companies. Although we are not interested in the differences in companies trading status per se, but rather on how they differ in their financing sensitivities, these differences raise some concerns regarding the comparability between groups. To that end, we also work with subsamples of matched companies, using 2 different matching procedures.

\section{Table 4 here}

Our matching procedure proceeds as follows: First, we use a subsample of privately held firmyear observations that match the observable characteristics of the publicly listed companies in our sample. In particular, for each public firm-year observation we select the nearest-neighbor match of private firm-year observations, in terms of Age, Products per Year and Sales (which is time invariant in our setting), using propensity score matching. ${ }^{18}$ As this method matches at the observation (firm-year) level, it maximizes the accuracy of the match. Some publicly listed firmyear observations could not be matched due to lack of common support in the distributions. The univariate differences for this matched sample are presented in Table 4, Panel B. As can be seen, most of the observable differences between groups - for variables other than external financing - are greatly reduced in this matched sample.

The main drawback of matching at the observation level — as described above — is that the matched subsample generated is not suitable for within-firm analysis. Matched pairs are not followed over time, as for every year different private firms may be the best match of a given

\footnotetext{
${ }^{18}$ We use sampling without replacement to avoid biasing the standard errors in the econometric analyses we perform.
} 
public company. As in some of our empirical analysis we study within firm variation, we also match firms using an alternative method that maximizes within-firm variation. To that end, we first consider only those publicly traded firms that operate during the 13 years of the sample. Then, we match them to an equal number of private firms that also operate for all 13 years, according to their 1998 characteristics - Age and Products per Year — and their Sales. Thus, we follow the matched pair over time. Again, we lose some public firms as there were no private firms with common support in the distribution. Our final sample consists of 63 matched pairs that operate through the whole sample period. The univariate differences for this subsample are presented in Table 4, Panel C. It is also the case that for this subsample most of the observable differences between groups — for variables other than external financing — are greatly reduced relative to the overall sample. ${ }^{19}$

\section{Empirical Strategy}

To analyze the impact of changes in investment opportunities on firms' external financing decisions we estimate several variations of the following baseline empirical model, which also includes firm fixed effects when we focus on within-firm variation:

$$
y_{i t}=\alpha+\beta * \text { Private }_{i t}+\gamma * N C D_{i t}+\delta * \text { Private }_{i t} * N C D_{i t}+\boldsymbol{\Omega}^{\prime} \boldsymbol{X}+\mu_{t}+\varepsilon_{i t}
$$

The subscript $i$ indexes firms and $t$ indexes years. The dependent variable yit represents either the logarithm of the dollar value of external funds raised in a year, or the indicator variable for an external financing transaction.

The parameter $\beta$ captures the differences in external financing between privately held and publicly traded companies. We expect this parameter to be negative as privately held companies typically obtain external financing less often and in smaller amounts than publicly traded companies (see

\footnotetext{
${ }^{19}$ External financing variables are the outcome variables in our empirical specification and thus we do not match on external financing decisions. Moreover, if we were to include public firms' 1998 external financing transactions to the list of variables that we match on, the number of matched pairs with common support reduces from 63 to 0 . This finding is unsurprising as external financing is lumpy and firms go public to get access to additional financing, making public and private firms very different in this dimension. The differences in external financing of public and private firms, not induced by NCDs, are controlled for in our empirical design by the inclusion of a dummy variable that captures the mean differences in external financing as discussed in the next section.
} 
Brav (2009)). The parameter $\gamma$ captures the effect of NCD approvals on external financing activities. As NCD represents an increase in investment opportunities, this parameter is expected to be positive: better investment opportunities may lead to more investment and additional funds may be needed. Our main parameter of interest is $\delta$. This parameter tells us whether private or public companies differ in their sensitivity to better investment opportunities. If $\delta$ is negative, private companies raise less external financing than publicly traded companies when facing better investment opportunities.

Key to our identification of the above parameters is that the differences between privately held and publicly traded companies are not driven by other characteristics that correlate with a firm's trading status. For example, publicly traded firms are typically larger and thus the differences we attribute to trading status may merely reflect differences in firms' size. To address this concern, we include a set of controls $\mathbf{X}$, including number of products introduced in a year, and their 2011 sales. This set of controls also include firms' age, as younger firms typically require more external financing than more mature firms. For some specifications we also interact these variables with the variable NCD to show that the results are not driven by the interaction of an increase in investment opportunities with variables that correlate with a firm's trading status.

In all our specifications we include year fixed effects, $\mu_{t}$, to control for unobserved macro shocks that may correlate with firms' financing activities (e.g., aggregate demand shocks, costs of funds, etc.). We estimate our results both with and without firm fixed effects. Using firm fixed effects has the advantage that it mitigates potential unobserved heterogeneity concerns, as this specification only exploits within firm variation. The disadvantage is that the coefficients of the variables Age, and Log(sales) cannot be estimated in such a setting. ${ }^{20}$ Another drawback is that the coefficient of the variable Private is only identified by those companies that underwent an IPO during the sample period.

One possible concern is that although we control for variables that may correlate with firms' listing status that can also affect firms' financing activities, it is still possible that there may not be common support in the controls variables for public and private firms. If that was the case, private

\footnotetext{
${ }^{20}$ The variable Age increases by 1 for all firms every year, so it is perfectly collinear with the constant term.
} 
and public firms would not be comparable and thus little could be learn from their differences in financing behavior. To address this concern, we replicate our estimation of equation (1) using two set of matched samples, described in Section III: one that maximizes the accuracy of the match, and another which is more suitable for the analysis of within firm variation. The estimations with matched data also help scaling firms' external financing transactions to their relevant characteristics, such as size and age.

In all specifications we adjust standard errors for heterocedasticity and product-line clustering. We cluster at the product-line level as demand shocks are at this level of aggregation. This clustering strategy accounts for 3 types of arbitrary correlations in the error term: 1.) Error correlation across different firms in a given product-line and year; 2.) Error correlation across different firms in a given product line over time; and 3.) Error correlation within the same firm over time (see Petersen 2009).

\section{Financing Results}

\section{A. Pooled Panel Regressions}

Table 5, Panel A, shows the results of panel regression for the baseline specification, using the complete sample. The first column runs a pooled OLS regression, using Log(Ext. Financing Amount) as dependent variable. The second column runs a linear probability model using the indicator variable for an Ext. Financing Transaction as dependent variable. In both these columns the control variables include Log(Products per year), Age and Log(Sales). We start with linear regression models as the coefficients are easier to interpret. Later, we allow for other model specifications.

\section{Table 5 here}

The results show that privately held companies obtain external financing much less frequently and in smaller amounts - than publicly traded companies. This result is consistent with Brav's (2009) findings. The results also show that NCD approvals have a strong positive effect on external financing, indicating the NCD approvals are expected to have an important effect on firms' future demand. This is consistent with the CAR evidence presented earlier. More importantly, the 
coefficient of the interaction between Private and NCD approval is negative and statistically significant. That is, publicly traded firms have higher financing sensitivity to improved investment opportunities than privately held firms. ${ }^{21}$ We interpret this coefficient as publicly traded firms having a potential advantage over privately held companies, in terms of how they react towards a positive shock to their investment opportunities. Finally, notice that the coefficients of the control variables have the signs that we expect: larger and younger corporations typically have more external financing transactions and raise more funds.

Columns III and IV replicate columns I and II, but include as additional controls the interaction between NCD approval, Log(Products per year), and Age with Log(Sales). These interactions are included to control for the possibility that firms' size and age — and not its trading status - is what drives the negative coefficient of the interaction between Private and NCD approval. The results show that this interaction term remains negative and statistically significant after the inclusion of these additional controls.

As the variable Log(Ext. Financing Amount) contains an important fraction of observations with zero values (i.e, when no external financing transaction occurred), we run a Tobit estimation in column $\mathrm{V}$ for robustness. We also replicate the results of the linear probability model on Ext. Financing Transaction using a Probit model in column VI. All the results hold.

In Table 5, Panel B, we replicate Panel A using the sample of matched observations at the firmyear level. The results are virtually unaltered in the matched sample. This indicates that differences among private and public firms do not play an important role when it comes to explaining the differential external financing sensitivity to investment opportunities we document.

\section{B. Within-Firm Panel Regressions}

One potential concern about the results presented in Table 5 is that firm unobserved heterogeneity may be biasing the coefficients. To mitigate this possibility, we include firm fixed-effects and re-

\footnotetext{
${ }^{21}$ The coefficient of the interaction term is negative, in spite of a potential bias in the other direction. Prior papers, such as Gao, Harford and Li (2013) and Farre-Mensa (2011, 2014), document that public firms hold more cash than privately held firms. For this reason, public firms may need less external financing than private firms to respond to improved investment opportunities. Thus, the coefficient we find on the interaction term can be considered a lower bound of the true coefficient that captures the differential external financing response of private and public firms to improved investment opportunities.
} 
estimate our results in Table 6. In this table, we only present the coefficients for the variables Private, NCD approvals, and the interaction of these two terms. All the time-variant control variables used in Table 5 are included, but omitted to preserve space. The first column uses the Log(Ext. Financing Amount) as the dependent variable and the second column uses the indicator variable for an Ext. Financing Transaction as the dependent variable. Columns III and IV repeat the estimation using a sample of private and public companies - matched on the first sample year — which tracks the same firms through time. As the private firms in this matched sample did not undergo any IPOs, the coefficient of the variable Private is dropped in this specification.

\section{Table 6 here}

The results obtained using firm-fixed effects are very similar to those obtained in the previous specifications, suggesting that firm unobserved heterogeneity was not driving the results. The economic effects of NCD approvals are summarized in Table 7. We use the regressions from the base case specification (Table 5, Panel A) to compute these effects. The fixed effect specifications and the matched regressions deliver very similar estimates.

\section{Table 7 here}

Our results indicate that for public firms, a NCD approval leads to a $10 \%$ unconditional increase in external funds raised; an increase in $10.2 \%$ in external funds raised, conditional on raising any funds in a given year; and a $4.2 \%$ increase in the probability of raising funds externally in a year. For private firms, the results are more modest: a NCD approval leads to a $1.6 \%$ unconditional increase in external funds raised; an increase in $4.2 \%$ in external funds raised, conditional on raising any funds in a given year; and a $0.6 \%$ increase in the probability of raising funds externally in a year. The economic effects and their differences between private and public firms are all statistically significant at conventional levels. ${ }^{22}$

\footnotetext{
${ }^{22}$ One potential concern is that Capital IQ or Deal Scan may register fewer transactions for private firms than for publicly traded firms. To the extent that this under sampling is somehow more severe for private firms affected by a NCD approval, this could bias the estimation of the differences in external financing sensitivity of public and private firms. Notice, however, that we find a substantially larger external financing sensitivity for public firms, even when we condition on observing an external financing transaction. In this scenario, this concern does not apply.
} 


\section{Timing of Financing}

In this section, we study the timing of financing relative to NCD approvals. Doing this is useful for 2 purposes. First, we run falsification tests on the parallel trend assumption by looking at whether the difference in external financing between private and public firms is widening the year prior a NCD approval. If that was the case, then we cannot rule out that the difference in external financing sensitivity to NCDs we find in our prior results is simply a consequence of prior ongoing trends. The finding of no significant differential effect the year prior to a NCD, however, would provide support for the parallel trends assumption that we have been implicitly maintaining so far in our empirical analysis.

Second, we can study the length of the effect of NCD approvals on firms' external financing. Our current definition of the NCD Approval variable assumes that NCDs are cumulative shocks: the variable NCD Approval increases by 1 unit for every approval and stays at that level until another approval arrives. The reason is that NCD approvals generate the need for additional funds, which may either materialize during the NCD approval year, or during later years. By studying the exact timing of the subsequent financing events we intend to provide further validity to our definition of the NCD Approval variable.

In particular, we replicate the full sample firm fixed effects estimations from Table 6, redefining NCD approvals as 1 period shocks. The results are shown in Table 8. Panel A shows the financing results for 1 year before NCD approvals (i.e., the NCD Approval dummy takes a value of 1 the year prior to NCD approval, and 0 otherwise), Panel B shows the results for the NCD approval year, and Panels C-F show the results for 1 to 4 years after an NCD approval.

\section{Table 8 here}

Panel A shows no significant differential effects in external financing for public and private firms on the year prior to a NCD approval. The coefficients of the NCD Approval dummy ( $t-1)$ and its interaction term with the dummy Private are not statistically significant and are of a much lower magnitude than those reported for subsequent years. Panel B shows that on the NCD year, public firms increase their external financing by more than private firms, and this difference is statistically significant at the $5 \%$ level. Also importantly, Panels C-F show that NCD approvals have important differential economic effects on financing for public and private firms even 3-4 years after the 
NCD approvals, although not all the large economic effects are statistically significant. The fact that the economic effect are longer than a single period justifies our earlier definition of the NCD approval variable as a cumulative shock.

Overall our results are very robust. They all indicate that publicly traded companies raise more external funds than privately held firms in the presence of improved investing opportunities. In the next section, we study the channel under which this financing advantage occurs.

\section{Which Securities Give the Financing Advantage to Publicly Traded Firms?}

There are two potential channels though which publicly traded firms may have an advantage in raising external financing in the presence of good investment opportunities. First, publicly traded firms have broader access to external financing: they can issue seasoned equity (SEOs) and can more easily issue corporate bonds - in addition to obtaining funds through privately placed equity, or bank debt, as privately held firms. Second, even if the type of securities through which financing is raised is the same as that of privately held firms, publicly traded firms may still have an advantage as they can offer better exit liquidity to private investors. That is, private investors may prefer to invest in private securities of publicly traded firms to have the option to liquidate their positions easily, if needed.

In this section we study through which securities the financing advantage is occurring. We estimate a multinomial logit of security issuance using NCD approvals as main explanatory variable. We estimate separate regressions for privately held and publicly traded companies, as their financing alternatives are different. For both estimations, the default option is "no external financing." For this analysis, we classify the IPO decision as taken by a privately held company, as the decision of undergoing an IPO is taken before the company changes its listing status. The control variables used for these estimations are Log(Products per year), Age and Log(Sales).

The estimation results are shown in Table 9. Panel A shows the results for privately held companies and Panel B shows the results for publicly traded firms. The results show that private companies have a statistically significant increase in venture capital and growth capital financing after a NCD approval. However, the estimated marginal effects are quite small. This fact, coupled with the low frequency of these financing events, translates into NCD approvals having a negligible economic 
effect on private firms' financing decisions. Publicly traded firms, on the other hand, have a sharp increase in private investments in public equity (PIPEs) of $25 \%$ - the probability that a firm raise funds through a PIPE transaction in a given year increases from $11.6 \%$ to $14.5 \%$.

\section{Table 9 here}

Overall, the results indicate that PIPEs — which represent $65 \%$ of the transactions for public companies - are driving the result that public firms react more to better investment opportunities than private firms. These results suggest that the advantage of being public for smaller public firms does not come from having better access to public markets, but rather to being able to offer liquid securities that private investors can easily sell later. As discussed earlier, when these securities are offered to private investors, the offering includes registration rights that require the company to register the securities with any public offering of stock and frequently has clauses that give the private investor more equity (payment-in-kind) if the security is not registered within a given period of time. Once registered these equity securities become identical to already traded public equity and shares are able to be sold in the public markets. Lastly, private investors can hedge the risk of these PIPE securities by shorting the publicly traded stock once the company discloses the sale in a filing with the SEC. Thus, while not initially sold in the public market, the existence of publicly traded equity is important.

To shed more light on our interpretation, we look for the description of some of the PIPE transactions in which firms affected by a NCD approval raised funds. This information is shown in Appendix A. The descriptions of the deals tend to highlight the availability of an "exit option" for investors. The securities issued in these transactions frequently contain these explicit conversion rights which allow private investors to convert into public equity at a later date, thus proving future liquidity to these investors.

\section{E. Acquisition Activity}

In our prior results we show that privately held firms raise less funds than similar publicly traded firms, in the presence of improved investment opportunities. One possible explanation is that private firms raise fewer funds simply because they are more likely to be acquired after NCD approvals in their product lines. We analyze this possibility by estimating a multinomial logit 
regression for private and public firms where the default option is that a firm is not involved in acquisition activity, and the other alternatives are that a firm is acquired, or it acquires another firm. The results are shown in Table 10. Panel A shows the results for privately held firms, while Panel B shows the results for publicly traded companies. As can be seen, neither private nor public firms are significantly more or less likely to be acquired or to acquire after NCDs. We do see that private firms with more products are in general more likely to be acquired and public firms with more products are more likely to be acquirers, but find no effect upon NCD approval. Our results thus do not support the proposition that private firms are acquired after NCD approvals as a substitute for raising external capital.

\section{Table 10 here}

\section{NCDs and Product Introductions}

While our prior results establish a relation between investment opportunities and different financing patterns of public and private firms, they do not address the consequences of obtaining additional financing. In principle, companies should use the funds they obtain to take advantage of the improved investment opportunities coming from NCD approvals (i.e., they should invest more). Unfortunately, we do not have time-series data on firms' R\&D or capital expenditures to directly test for this. However, we do have data on firms' FDA approved product introductions/modifications. Therefore, we study whether product introductions (or modifications of existing products), which are a long-run consequence of investments, are differentially affected for privately held and publicly traded firms.

We first examine graphically the differences in product introductions in figures 1 and 2, followed by multivariate regression analysis where we use a negative binomial model to examine the number of product introductions following NCD approval decisions. Figure 1 shows the evolution of product introductions for 4 groups of firms: publicly traded firms operating in a product line that did not receive a NCD approval during 1998-2010; publicly traded firms operating in a product line that received one (or more) NCD approval(s) during 1998-2010; privately held firms operating in a product line that did not receive a NCD approval during 1998-2010; and privately held firms operating in a product line that received one (or more) NCD approval(s) during 1998-2010. We 
set the growth rate equal to 1 for all groups in 1998, and for each group-year we add the average within-firm product introduction yearly growth rate to plot each group's product introduction trend over the sample period. The figure shows that publicly traded firms operating in product categories that received a NCD approval during the sample period increase their product introduction rate by more than publicly traded firms not affected by NCDs. Importantly, this difference is remarkably more pronounced than the difference in product introduction rates observed for private firms affected and not affected by NCD approvals. Thus, NCD approvals have a differential effect on product introduction among publicly traded and privately held firms. This is consistent with publicly traded firms being able to capitalize on their external financing advantage over privately held firms.

\section{Figures 1 and 2 here}

Although Figure 1 shows substantial differences in product introduction growth rates among privately held and publicly traded firms - both affected and unaffected by NCD approvals - it is still possible that these differences were driven by prior trends. Perhaps publicly traded firms affected by NCD approvals were growing faster than firms in the other groups, even prior to NCD approvals. In that case, the faster growth rate displayed by publicly traded firms affected by NCD approvals should not be considered as evidence of NCD approvals causing higher product introduction rates, through any channel.

To address the issue related with potentially pre-existing trends, we replicate Figure 1, but considering only a subset of firms that received NCD approvals in a single year, during a fairly long time period: we only include firms in the Anesthesiology and Gastroenterology/Urology product categories. These product categories received NCD approvals in 2001, and had no NCD approvals either between 1998 and 2001, or from 2002 to 2007, giving us enough pre and post treatment years to analyze product introduction trends. The product introduction trends are shown in Figure $2 .{ }^{23}$

Figure 2 shows that publicly traded firms in the treated product categories do not have any indication of higher product introduction growth rates, prior to 2001, than firms in the other groups.

${ }^{23}$ This type of figure is often referred to as "dynamic graph" in a Diff-in-Diff analysis. 
This implies that the differential effect of NCDs on product introduction rates for public and private firms cannot be attributed to prior ongoing trends. Actually, only 2-3 years after the NCD approval is when publicly traded firms in the Anesthesiology and Gastroenterology/Urology categories have a change in their product introduction trend. This delay is consistent with the timings in the medical device industry: It usually takes about 12-24 months to produce device improvements, between 6-24 months to obtain FDA approval on product introductions/modifications, and financing may come with delay, too.

Lastly we examine new product introductions in a multivariate setting. We run regressions where the dependent variable is the number of products introduced by firms from year " $\mathrm{t}$ " to " $\mathrm{t}+\mathrm{x}$," where $\mathrm{x}=\{1,2,3,4\}$. The main explanatory variables are the dummy Private, the variable NCD Approval, and the interaction term between these variables. We also include as control variables firm age, $\log$ of sales and year fixed effects. As the number of products introduced between " $t$ " and " $t+x$ " is a count variable with overdispersion (i.e, the variance is higher than the mean), we run negative binomial regressions. We cluster the standard errors at the product category level. The results are shown in Table 11. The economic effects are shown in the bottom rows of the table.

\section{Table 11 here}

The results in Table 11 indicate that firms affected by NCD approvals tend to introduce more products, and that the differences in product introduction between private and public firms widens after NCD approvals. Overall, the higher product introduction that publicly traded firms display after a NCD approval is consistent with these firms having a financing advantage, as these firms have better access to external funds when investment opportunities improve.

\section{Selection of Firms into Public/Private Status}

In this section, we examine whether publicly traded firms' financing advantage causes firms to choose their organizational type based on their investment opportunities. Offsetting the financing advantage, being publicly traded is costly (underwriter fees, underpricing, information disclosure costs, separation of ownership and control). Thus, we examine whether those firms that benefit enough from the financing advantage of being publicly traded - firms with higher returns to investment opportunities — self-select to be publicly traded. 
We look at firms' characteristics, previously used to match private and public firms, to study whether in the overall population firms display differences according to their trading status, which are consistent with more productive firms self-selecting to be publicly traded. First, we examine product introductions for private firms that go public, in the four years prior to their IPO, and compare them to private firms that remain private. This evidence is presented in Table 12, Panel A. The table shows that the average of products introduced per year is larger for private firms becoming public than for a sample of private firms (matched on age and year) that did not go public, and the difference is statistically significant at the $10 \%$ level. Moreover, in the two years prior to their IPO the difference is particularly pronounced, being is statistically significant at the $5 \%$ level.

\section{Table 12 here}

In addition, for a subset of firms for which we have data on their 2011 sales, we are also able to obtain data on their 2011 employees. With this information, we construct the ratio of sales to employees as a measure of firms' productivity. We compare public firms with a set of private firms, matched by age. We show this evidence in Panel B of Table 12. The mean sales per employee for public and private firms are approximately $\$ 192,000$ and $\$ 116,000$, respectively; and the difference of $\$ 76,000$ is statistically significant at the $1 \%$ level. The evidence on ex ante selection presented here is consistent with evidence presented earlier (Figures 1 and 2; Table 11), showing that publicly traded firms not affected by NCD approvals introduce more products than privately held firms not affected by NCD approvals. $^{24}$

Overall, the evidence is consistent with firms with higher returns to investment opportunities prepositioning themselves as publicly traded firms in order to take advantage of lower cost financing when good opportunities arise. Thus, the magnitude of the financing benefit we document (Table 7) has two components: A financing advantage of being publicly traded that accrues to any random private firm; and an additional financing benefit accrued for those firms which benefit the most from the financing advantage. ${ }^{25}$ The firms that benefit the most from

\footnotetext{
${ }^{24}$ The argument that publicly traded firms' financing advantage has a product market impact relates to the differential impact of NCD for public and private firms. The selection argument looks at firms' product introduction rates levels. ${ }^{25}$ The self-selection component helps explaining why the economic effect of a NCD approval on an IPO event is small (Table 9, Panel A), and why so few private firms (22 out of 1,721) go public during our sample period (13 years).
} 
possible improvements to their investment opportunities are likely to be public prior to the realization of good investment opportunities.

Disentangling the exact magnitude of financing advantage of being publicly traded from the selfselection component is challenging. Actually, we would require a natural experiment that sorts firms into public and private status, on top of the quasi-natural experiment we use to identify the casual effect of shocks to investments opportunities on external financing for private and public firms. This exercise is beyond the scope of the paper. However, it is important to notice that it is extremely unlikely that firm selection by itself can be the exclusive driver of the differences in external financing sensitivity we document, for two reasons. First, our results are virtually unaffected when we match on dimensions that correlate with firms' productivity, such as sales and product introductions. Second, in the absence of a financing advantage, we should not observe more productive firms becoming publicly traded, as we show in the overall sample. Other commonly given explanations for going public (e.g., investors' need to cash out) do not induce a sorting of firms according to their productivity. That is, the reason for the selection effect is the financing advantage itself.

\section{Conclusions}

We examine the financing decisions and product introductions of private and public firms after exogenous changes to their investment opportunities in the medical device industry. The medical device industry is an ideal industry to examine whether being publicly traded confers advantages or disadvantages as this industry contains over 1,800 small private and public firms that produce in a single product category. We use Medicare national coverage decisions as exogenous shocks to firms' investment opportunities. Medicare national coverage approval decisions for national coverage represent large positive shocks to product demand for both publicly traded and private firms. We find that public companies increase their external financing and introduce more products than private companies in response to these national coverage approvals. Our results are robust to the inclusion of variables that control for firm size, to different matching procedures, and to the inclusion of firm fixed-effects. 
We show that private market securities issued by public firms explain why publicly traded firms have a higher financing response to these Medicare coverage decisions. Public firms have a sharp increase in private investments in public equity (PIPEs) post-NCD approval of 25 percent. Interestingly, the increased probability of a public firm raising financing through a seasoned equity offering (SEO) is lower than that of a private firm raising financing through venture capital (VC) or private equity after a $\mathrm{NCD}$.

These findings highlight that there is an important financing advantage for public firms other than merely having access to funds in the public markets. In our setting, publicly traded firms' financing advantage comes from offering securities with better exit liquidity and less price risk in the private markets. PIPE securities offer better exit liquidity than private placements in private firms, as these securities are typically registered with the SEC within six months to one year, allowing private investors to sell them when they are registered. PIPE securities also offer lower price risk than private placements in private firms, as private investors have a benchmark public reference price and they can hedge their risk in these securities by selling the public equity short in the period prior to the securities being registered. In contrast, private investments in privately held companies have more price risk and are relatively more difficult to sell than PIPEs. Our results are consistent with these features making investment in publicly traded companies through private equity more attractive to private investors that value liquidity and reduced price risk.

We show that the increased ability to raise external capital of public firms is associated with positive product market outcomes. We find that publicly traded firms operating in product categories that receive a NCD approval during the sample period increase their product introduction rate by more than that of private firms affected by a NCD.

Consistent with the financing advantage we document, we find that firms chose their organizational type based on their investment opportunities: higher quality firms select to go public prepositioning themselves as public firms, bearing the costs of being public. Our results are consistent with firms with better investment opportunities bearing the costs of being public to take advantage of lower cost financing available to public firms when responding to investment opportunities. Firms whose investment opportunities are lower or who have higher costs of going public, stay private and access less external financing. 
Overall, our results are consistent with an important financing advantage of public firms that allows them to take advantage of positive exogenous changes in investment opportunities. This financing advantage allows publicly traded firms to introduce more new products in the face of better product market opportunities. 


\section{References}

Ali, Ashiq, Sandy Klasa and Eric Yeung. 2014. Industry Concentration and Corporate Disclosure Policy. Journal of Accounting and Economics, forthcoming.

Asker, John, Joan Farre-Mensa, and Alexander Ljungqvist. 2013. Corporate Investment and Stock Market Listing: A Puzzle? Working paper, Harvard University.

Bernstein, Shai. Does Going Public Affect Innovation? Working paper, Stanford University.

Brav, Omer. 2009. Access to Capital, Capital Structure and Funding of the Firm. Journal of Finance 64(1), 263-308.

Brophy, David, Paige Ouiment, Clemens Sialm. 2009. Hedge Funds as Investors of Last Resort. Review of Financial Studies 22 (2), 541-574.

Card, David, Carlos Dobkin and Nicole Maestas. 2008. The Impact of Nearly Universal Insurance Coverage on Health Care Utilizations: Evidence from Medicare. American Economic Review, 98(5).

Chambers, James, Steven Morris, Peter Neumann and Martin Buxton. 2012. Factors Predicting Medicare National Coverage: An Empirical Analysis. Medical Care, 50:3.

Chaplinsky, Susan and David Haushalter. 2010. Financing Under Extreme Uncertainty: Evidence from Private Investments in Public Equities. Review of Financial Studies 23 (7):2789-2820.

Farre-Mensa, Joan. 2011. Why are Most Firms Privately Held? Working paper, Harvard University.

Farre-Mensa, Joan. 2014. Comparing the Cash Policies of Public and Private Firms. Working paper, Harvard University.

Finkelstein, Amy and Robert McKnight. 2008. What did Medicare do? The initial impact of Medicare on mortality and out of pocket medical spending. Journal of Public Economics, 92:7.

Foote, Susan. 2002. Why Medicare Cannot Promulgate a National Coverage Rule: A Case of Regula Mortis. Journal of Health Politics, Policy and Law, 27:5.

Gaziano, Thomas A 2006. Reducing the growing Burden of Cardiovascular Disease in the Developing Workls. Health Affairs, 26:1

Gao, Huaseng, and Kai Li. 2013. Ownership Concentration and CEO Pay-Performance Sensitivity: New Evidence from Privately-Held Firms, Working paper, University of British Columbia.

Gao, Huaseng, Jarrad Harford and Kai Li. 2013. Determinants of Corporate Cash Policy: Insights from Private Firms, Journal of Financial Economics, 109, 623-639.

Gianetti, Mariassunta. 2003. Do Better Institutions Mitigate Agency Problems? Evidence from Corporate Choices. Journal of Financial and Quantitative Analysis, 38(1), 185-212. 
Gilje, Eric, and Jerome Taillard. Do Public Firms Invest Differently than Private Firms?, Working paper, Boston College.

Gillick, Muriel. 2004. Medicare Coverage for Technological Innovations ---Time for New Criteria? New England Journal of Medicine, 350: 2199-2203.

Gomes, Armand, and Gordon Phillps. 2012. Why do Public Firms Issue Private and Public Securities? Journal of Financial Intermediation, 2012, 21 619-658.

Holtzman, Yair. The U.S. Medical Device Industry in 2012: Challenges at Home and Abroad. WTP advisors report.

Houston, John and Sari Laitin, 2000, The SEC Adopts New Regulations to Curb Selective Disclosure, http://rkmc.com/article.asp?articleId=137, Robins, Kaplan, Miller and Ciresi L.L.P.

Maksimovic, Vojislav, Gordon Phillips and Liu Yang. 2013. Private and Public Merger Waves, Journal of Finance 68(5): 2177-2217.

Michaely, Roni, and Michael Roberts. 2012. Corporate Dividend Policies: Lessons from Private Firms, Review of Financial Studies 25(3): 711-746.

Mortal, Sandra, and Natalia Riesel. 2012. Capital Allocation by Public and Private Firms. Journal of Financial and Quantitative Analysis 78, 77-103.

Neuman, Peter, Makl Kamae and Jennifer Palmer. 2008. Medicare's National Coverage Decisions For Technologies, 1999-2007. Health Affairs, 27:6.

Petersen, Micheal. 2009. Estimating Standard Errors in Finance Panel Data Sets: Comparing Approches. Review of Financial Studies 22, 435-480.

Saunders, Anthony, and Sascha Steffen. 2011. The Costs of Being Private: Evidence from the Loan Market. Review of Financial Studies 24(12):4091-4122.

Sheen, Albert. 2009. Do Public and Private Firms Behave Differently? Working Paper, Harvard University.

Thorpe, Kenneth E., Curtis S. Florence, David H. Howard, 2012. "Trends: The Impact Of Obesity On Rising Medical Spending” Health Affairs, 4:31.

Tunis, Sean, Robert Berenson, Steve Phurrough and Penny Mohr. 2011. Improving the Quality and Efficiency of the Medicare Program Through Coverage Policy. Robert Wood Johnson Foundation.

Weisfeldt, Myron and Susan Zieman. 2012. Advances in The Prevention And Treatment Of Cardiovascular Disease. Health Affairs, 31:4. 


\section{Figure 1}

\section{Product Introduction Trends by Subgroups of Public/Private firms with/without NCD Approvals in their Product Category}

This figure shows product introduction trends for companies that operated through 1998-2010, according to whether their product categories received NCD approvals throughout the sample, and their trading status (public/private). We set the growth rate equal to 1 for all groups in 1998, and for each group-year we add the average within-firm product introduction yearly growth rate to plot each group's product introduction trend over the sample period.

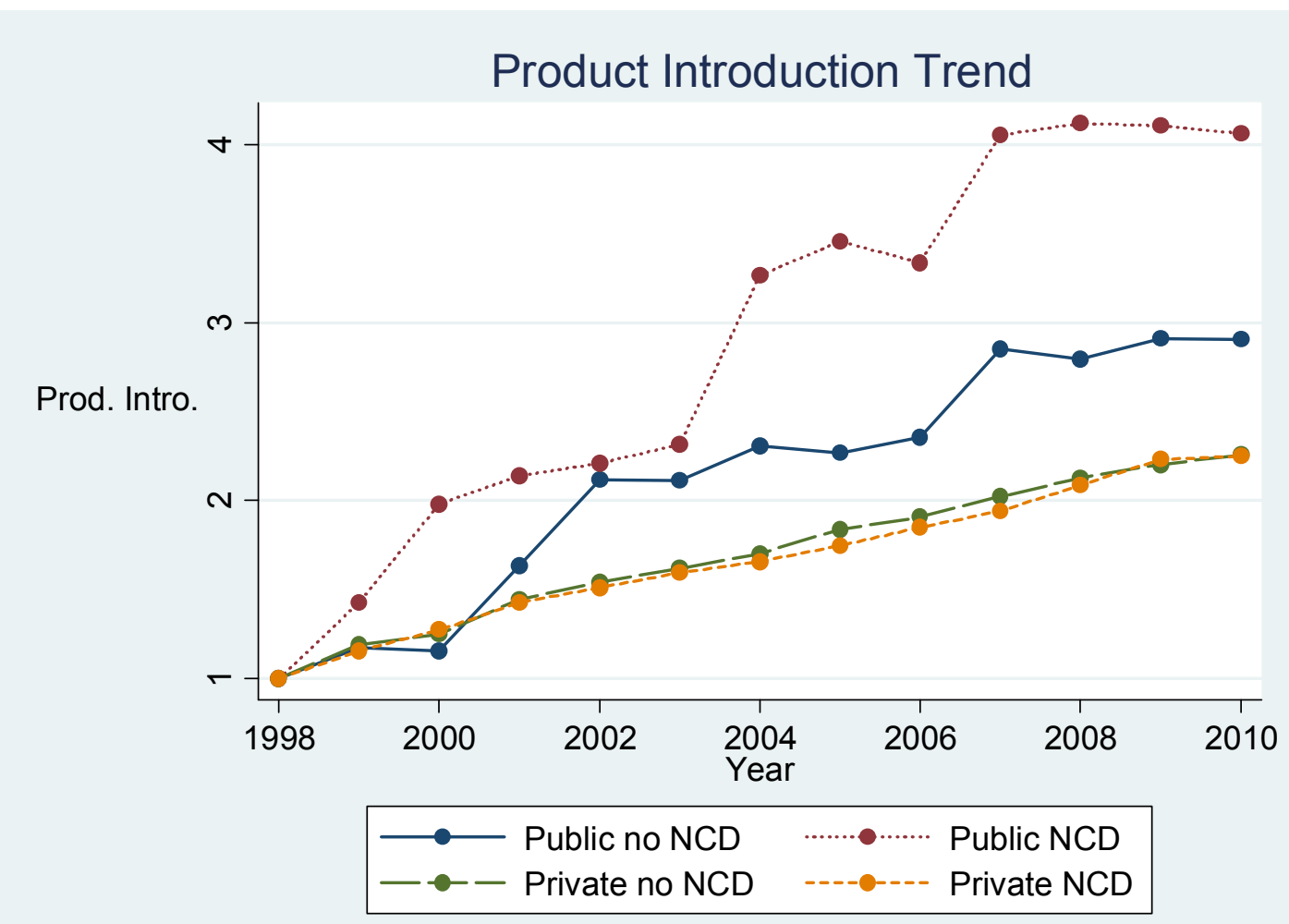


Figure 2

\section{Product Introduction Trends for companies in the Anesthesiology and Urology category and companies without NCD approval}

This figure shows product introduction trends for companies that operated through 1998-2007, using firms from the Anesthesiology and Urology categories - which received NCD approvals on 2001 - and firms operating in product categories that did not receive a NCD approval during the sample period. We set the growth rate equal to 1 for all groups in 1998, and for each group-year we add the average within-firm product introduction yearly growth rate to plot each group's product introduction trend over the sample period.

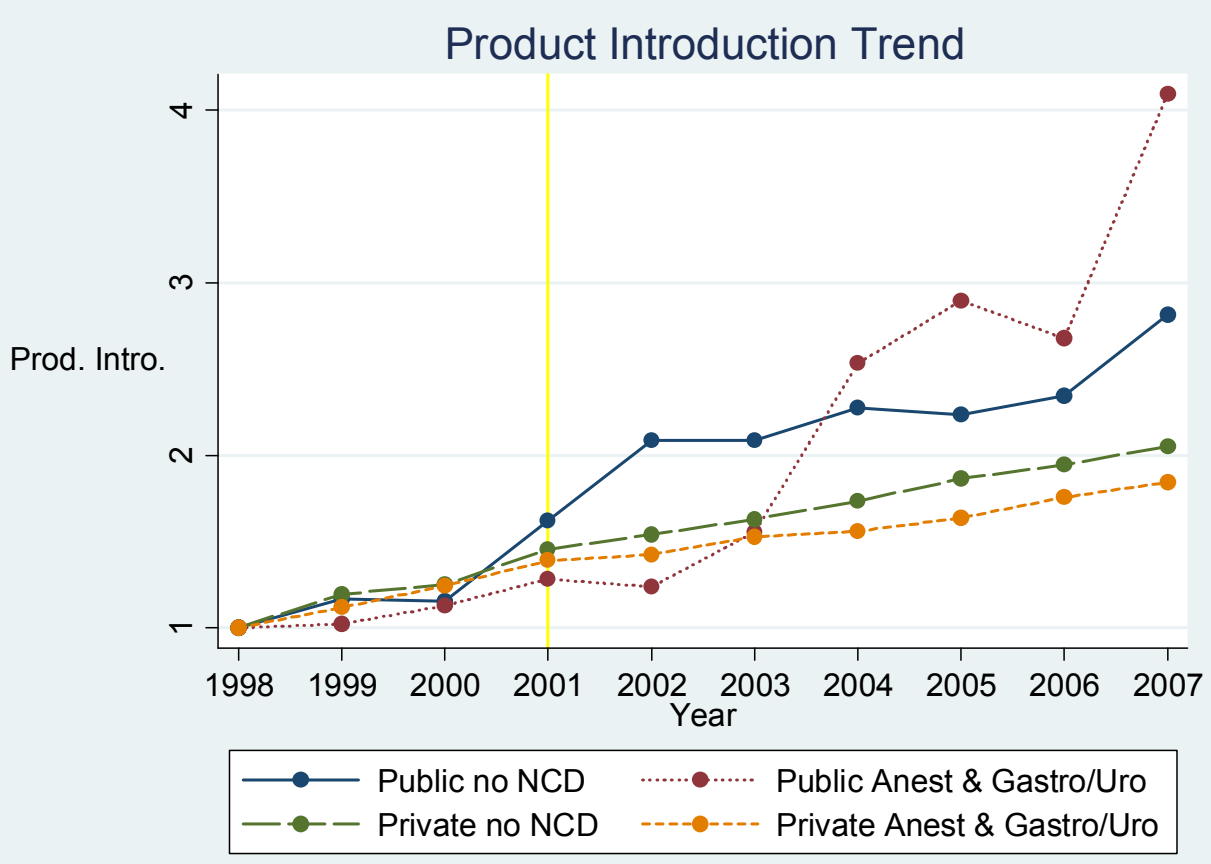




\section{Table 1}

\section{National Coverage Decision Approvals and Extensions for 1998-2010}

Panel A summarizes the 17 national coverage decision (NCD) approvals issued by Medicare during 1998-2010. Column I shows the FDA product category of each device. Column II shows the name of the device that obtained national coverage approval. Column III shows the year in the sample period in which the device was first approved - or the first year in the sample period the device was granted extended coverage if some initial coverage was approved before 1998. Columns IV and V show the year in which some of the devices obtained extended coverage during the sample period. Column VI shows the year in which the device was initially approved, in case the initial approval was prior 1998. Column VII shows the review process under which manufacturers need to submit their applications to get FDA approval on each device. Panel B shows the product categories that did not receive a NCD approval during the sample period. Panel C shows the results of an event study of firms' returns, using NCD approvals/extensions by Medicare as events. The firms analyzed are publicly traded firms operating in product categories affected by a NCD approval. Excess stock returns are calculated over a single factor model with parameters estimated over a 200 day interval $(-300,-100)$. Significant at: $* 10 \%$, and $* * 5 \%$.

Panel A

\begin{tabular}{|c|c|c|c|c|c|c|}
\hline FDA Device Classification & Medical Device & First Appr, in Sample & First Exten, in Sample & Second Exten, in Sample & Initial Appr. & FDA Review Process \\
\hline Anesthesiology (AN) & Continuous Positive Airway Pressure (CPAP) Therapy & 2001 & 2008 & & 1986 & $510 \mathrm{~K}$ \\
\hline Cardiovascular (CV) & Implantable Automatic Defibirillators & 1999 & 2003 & 2004 & 1986 & PMA \\
\hline Cardiovascular (CV) & Artificicial Hearts and Related Devices (VAD) & 2003 & 2010 & & 1993 & PMA \\
\hline Ear Nose \& Throat (EN) & Speech Generating Devices & 2001 & & & & PMA \\
\hline Ear Nose \& Throat (EN) & Cochlear Implantation & 2004 & & & 1986 & PMA \\
\hline Gastroenterology/Urology (GU) & Sacral Nerve Stimulation For Urinary Incontinence & 2001 & & & & PMA \\
\hline Gastroenterology/Lrology (GU) & Non-Implantable Pelvic Floor Electrical Stimulator & 2001 & & & & $510 k$ \\
\hline General Hospital (HO) & Infusion Pumps & 2004 & & & 1984 & PMA \\
\hline Neurology (NE) & Vagus Nerve Stimulation (VNS) & 1999 & & & & PMA \\
\hline Neurology (NE) & Deep Brain Stimulation & 2002 & & & & PMA \\
\hline Physical Medicine (PM) & Neuromuscular Electrical Stimulation (NMES) & 2002 & & & & $510 K$ \\
\hline Physical Medicine (PM) & Mobility Assistive Equipment(MAE) & 2005 & 2007 & & & $510 \mathrm{~K}$ \\
\hline
\end{tabular}




\section{Panel B}

FDA Device Classification with no NCD

Approval/Extension during the sample period: 1998-2010

Clinical Chemistry $(\mathrm{CH})$

$$
\text { Dental (DE) }
$$

Hematology (HE)

Inmunology (IM)

Microbiology (MI)

Obstetrics/Gynecology (OB)

Ophthalmic (OP)

Orthopedic (OR)

Pathology (PA)

Radiology (RA)

Surgery (SU)

Toxicology (TX)

\section{Panel C}

\begin{tabular}{cc}
\hline Event Window & CAR \\
\hline$-90,+90$ & $21 \% * *$ \\
$-90,+60$ & $15.3 \% *$ \\
$-60,+60$ & $11.8 \% *$ \\
$-10,+10$ & $2.6 \%$ \\
\hline
\end{tabular}




\section{Table 2}

\section{Summary Statistics}

This table shows the summary statistics for our sample. External Financing Amount represents the yearly amount of external financing raised by the companies in our sample. If a company does not raise funds externally in a year, this variable takes a value of 0; if it does, it takes the transaction amount. External Financing Transaction takes a value of 0 if a firm did not obtain external financing in a year, and 1 if it obtained external financing. The variable Private is a dummy variable which takes a value of 0 if a company was publicly listed in a year, and 1 otherwise. The variable NCD Approval takes a value of 0 if a company operates in a product line without a NCD approval during the sample period, or in the years prior to a NCD approval. This variable increases its value by 1 if in its product line it receives a NCD approval or extension. Products per year is the number of FDA approved new products and approved modifications to existing products granted to a firm in a year. The variable Age is the year of operations minus the founding year, and Sales represent the 2011 sales of a company in millions of dollars.

\begin{tabular}{ccccc}
\hline Variable & Mean & Pctile 50 & sd & N \\
\hline Ext. Fin. Amount (US\$ million) & 0.65 & 0.0 & 5.7 & 19217 \\
Ext. Fin. Transaction & 0.03 & 0.0 & 0.2 & 19217 \\
Private & 0.93 & 1.0 & 0.2 & 19217 \\
NCD Approval & 0.69 & 0.0 & 1.2 & 19217 \\
Products per year & 0.61 & 0.0 & 3.5 & 19217 \\
Age & 16.55 & 12.0 & 17.5 & 19217 \\
Sales (US\$ million) & 13.27 & 2.7 & 30.6 & 19217 \\
\hline
\end{tabular}




\section{Table 3}

\section{External Financing Transactions}

Panels A and B show the transaction types and average dollar value per transactions for subsamples of private and publicly traded companies. The external financing transactions of privately held firms include Private Equity, Initial Public Offerings (IPO), Venture Capital and Bank Loans. The external financing transactions of publicly traded firms include Fixed Income Offerings, Seasoned Equity Offerings (SEO), Private Investments in Public Equity (PIPE) and Bank Loans.

Panel A: Transaction Types and Values for Private firms (17,916 firm-year obs; 1,721 firms)

\begin{tabular}{cccc}
\hline Transaction Type & Number of Transactions (\#) & \% of Deals & Average Transaction Value (USS Million) \\
\hline Private Equity & 102 & $23 \%$ & 16.1 \\
IP0 & 22 & $5 \%$ & 56.7 \\
Venture Capital & 306 & $68 \%$ & 14.1 \\
Bank Loan & 21 & $5 \%$ & 36.3 \\
\hline Total & 451 &
\end{tabular}

Panel B: Transaction Types and Values for Public firms (1,301 firm-year obs; 119 firms)

\begin{tabular}{cccc}
\hline Transaction Type & Number of Transactions (\#) & \% of Deals & Average Transaction Value (US\$ Million) \\
\hline Fixed Income Offering & 5 & $2 \%$ & 49.6 \\
Seasoned Equity Offering & 37 & $16 \%$ & 53.7 \\
PIPE & 148 & $65 \%$ & 12.4 \\
Bank Loan & 36 & $16 \%$ & 21.7 \\
\hline Total & 226 &
\end{tabular}




\section{Table 4}

\section{Univariate Analysis}

Panel A shows the differences in variable means for publicly traded and private firms for the main sample. Panels B and $\mathrm{C}$ compare the public firms with two subsamples of matched observations. To construct the first matched sample we matched publicly traded firm-years to privately held firm-years on Products per year, age and Sales, using propensity score matching. This sampling procedure maximizes the accuracy of the match. The observable differences for this subsample are presented in Panel B. To construct the second subsample we only consider those publicly traded firms that operate during the whole sample period (i.e., 13 years). Then, we match them to an equal number of private firms that also operate for all 13 years, according to sales, and to their age and number of products introduced in 1998. Significant at: $* 10 \%, * * 5 \%$ and $* * * 1 \%$.

\begin{tabular}{cccc} 
Panel A: Full Sample & & & \\
\hline Variable & Public (N=1301) & Private (N=17916) & Difference (Public-Private) \\
\hline Ext. Fin.Amount (US\$ million) & 4.52 & 0.37 & $4.15^{* * *}$ \\
Ext. Fin. Transaction & 0.18 & 0.02 & $0.16^{* * *}$ \\
NCD Approval & 0.86 & 0.68 & $0.18^{* * *}$ \\
Products per year & 3.42 & 0.41 & $3.01^{* * *}$ \\
Age & 17.41 & 16.49 & $0.92^{*}$ \\
Sales (US\$ million) & 34.28 & 11.77 & $22.5^{* * *}$ \\
\hline
\end{tabular}

Panel B: Matched Sample, maximum accuracy

\begin{tabular}{|c|c|c|c|}
\hline Variable & Public (N=1214) & Private $(\mathrm{N}=1214)$ & Difference (Public-Private) \\
\hline Ext. Fin.Amount (US\$ million) & 3.90 & 0.49 & $3.4^{* * *}$ \\
\hline Ext. Fin. Transaction & 0.17 & 0.03 & $0.14 * * *$ \\
\hline NCD Approval & 0.80 & 0.65 & $0.15^{* *}$ \\
\hline Products per year & 1.01 & 1.02 & -0.01 \\
\hline Age & 17.26 & 18.64 & $-1.37 * *$ \\
\hline Sales (US\$ million) & 29.67 & 27.01 & 2.66 \\
\hline \multicolumn{4}{|c|}{ Panel C: Matched Sample, suitable for within firm analysis } \\
\hline Variable & Public $(\mathrm{N}=819)$ & Private $(\mathrm{N}=\mathbf{8 1 9})$ & Difference (Public-Private) \\
\hline Ext. Fin.Amount (US\$ million) & 1.98 & 0.07 & $1.91^{* * *}$ \\
\hline Ext. Fin. Transaction & 0.15 & 0.01 & $0.14^{* * *}$ \\
\hline NCD Approval & 0.74 & 0.70 & 0.04 \\
\hline Products per year & 0.91 & 0.27 & $0.59 * * *$ \\
\hline Age & 18.93 & 18.44 & 0.49 \\
\hline Sales (US\$ million) & 19.63 & 14.68 & 4.76 \\
\hline
\end{tabular}




\section{Table 5}

\section{Private and Public External Financing Sensitivity to Investment Opportunities}

This table presents regressions examining external financing sensitivity to NCD approvals. Panel A presents regressions examining external financing transactions and amounts using the full sample. Panel B presents regressions examining external financing transactions and amounts using a subsample of firm-year matched firms. In columns I, III and V the dependent variable is the logarithm of external financing amount in the years in which external financing was raised and zero otherwise. In columns II, IV and VI the dependent variable is an indicator variable that equals one if the firm raises external capital in a given year and zero otherwise. Investment opportunities are measured by the variable NCD Approval, which takes a value of 0 for firm-years not affected by NCD Approvals, and increases by 1 for every NCD approval in the product line of the firm. Significant at: $* 10 \%, * * 5 \%$ and $* * * 1 \%$. Standard errors are adjusted for heteroscedasticity and clusters at the product category level.

\section{Panel A: Full Sample}

\begin{tabular}{|c|c|c|c|c|c|c|}
\hline \multirow[b]{2}{*}{ Variable } & \multicolumn{4}{|c|}{ OLS } & \multirow{2}{*}{$\frac{\text { Tobit }}{\log (\text { Ext. Fin.Amount) }}$} & \multirow{2}{*}{$\begin{array}{c}\text { Probit } \\
\text { Ext. Fin. Transaction }\end{array}$} \\
\hline & Log(Ext. Fin.Amount) & Ext. Fin. Transaction & Log(Ext. Fin.Amount) & Ext. Fin. Transaction & & \\
\hline Private & $\begin{array}{c}-0.3116 * * * \\
(0.0670)\end{array}$ & $\begin{array}{c}-0.1105^{* * *} \\
(0.0289)\end{array}$ & $\begin{array}{c}-0.3094 * * * \\
(0.0679)\end{array}$ & $\begin{array}{c}-0.1101 * * * \\
(0.0294)\end{array}$ & $\begin{array}{l}-4.4619 * * * \\
(0.3923)\end{array}$ & $\begin{array}{c}-0.9721^{* * *} \\
(0.1008)\end{array}$ \\
\hline NCD Approval & $\begin{array}{c}0.1005^{* * *} \\
(0.0187)\end{array}$ & $\begin{array}{c}0.0445^{* * *} \\
(0.0067)\end{array}$ & $\begin{array}{c}0.1100 * * * \\
(0.0191)\end{array}$ & $\begin{array}{c}0.0560^{* * *} \\
(0.0081)\end{array}$ & $\begin{array}{c}1.0905 * * * \\
(0.2383)\end{array}$ & $\begin{array}{c}0.2983 * * * \\
(0.0506)\end{array}$ \\
\hline Private*(NCD approval) & $\begin{array}{c}-0.0839 * * * \\
(0.0176)\end{array}$ & $\begin{array}{c}-0.0385^{* * *} \\
(0.0081)\end{array}$ & $\begin{array}{c}-0.0802^{* * *} \\
(0.0184)\end{array}$ & $\begin{array}{c}-0.0409 * * * \\
(0.0087)\end{array}$ & $\begin{array}{c}-0.4015^{* * *} \\
(0.1468)\end{array}$ & $\begin{array}{c}-0.1314 * * * \\
(0.0323)\end{array}$ \\
\hline Log(products per year) & $\begin{array}{c}0.0591^{* * *} \\
(0.0149)\end{array}$ & $\begin{array}{c}0.0159 * * * \\
(0.0040)\end{array}$ & $\begin{array}{c}0.0255 \\
(0.0187)\end{array}$ & $\begin{array}{c}0.0174 * * * \\
(0.0059)\end{array}$ & $\begin{array}{c}1.4743^{* * *} \\
(0.3655)\end{array}$ & $\begin{array}{c}0.3278 * * * \\
(0.0811)\end{array}$ \\
\hline Age & $\begin{array}{c}-0.0028 * * * \\
(0.0006)\end{array}$ & $\begin{array}{c}-0.0012 * * * \\
(0.0002)\end{array}$ & $\begin{array}{c}-0.0019 * * * \\
(0.0006)\end{array}$ & $\begin{array}{c}-0.0009 * * * \\
(0.0002)\end{array}$ & $\begin{array}{c}-0.1523^{* * *} \\
(0.0291)\end{array}$ & $\begin{array}{c}-0.0334 * * * \\
(0.0058)\end{array}$ \\
\hline Log(sales) & $\begin{array}{c}0.0366 * * * \\
(0.0076)\end{array}$ & $\begin{array}{c}0.0107 * * * \\
(0.0029)\end{array}$ & $\begin{array}{c}0.0286 * * * \\
(0.0088)\end{array}$ & $\begin{array}{c}0.0113^{* * *} \\
(0.0034)\end{array}$ & $\begin{array}{c}0.9674 * * * \\
(0.1580)\end{array}$ & $\begin{array}{c}0.2012 * * * \\
(0.0328)\end{array}$ \\
\hline (NCD approval)*Log(products per year) & & & $\begin{array}{c}0.0138 \\
(0.0087)\end{array}$ & $\begin{array}{l}-0.0008 \\
(0.0021)\end{array}$ & $\begin{array}{c}-0.2423^{* * *} \\
(0.0860)\end{array}$ & $\begin{array}{c}-0.0554 * * * \\
(0.0206)\end{array}$ \\
\hline (NCD approval)*Age & & & $\begin{array}{c}-0.0016^{* * *} \\
(0.0005)\end{array}$ & $\begin{array}{c}-0.0005 * * * \\
(0.0002)\end{array}$ & $\begin{array}{l}-0.0124 \\
(0.0098)\end{array}$ & $\begin{array}{l}-0.0036 \\
(0.0022)\end{array}$ \\
\hline (NCD approval)* Log(sales) & & & $\begin{array}{c}0.0087 \\
(0.0061)\end{array}$ & $\begin{array}{c}0.0000 \\
(0.0018)\end{array}$ & $\begin{array}{c}-0.1048^{* *} \\
(0.0495)\end{array}$ & $\begin{array}{c}-0.0289 * * * \\
(0.0106)\end{array}$ \\
\hline Year Fixed Effects & Yes & Yes & Yes & Yes & Yes & Yes \\
\hline Product Category Cluster & Yes & Yes & Yes & Yes & Yes & Yes \\
\hline R-squared & 0.077 & 0.076 & 0.081 & 0.079 & 0.14 & 0.18 \\
\hline $\mathbf{N}$ & 19217 & 19217 & 19217 & 19217 & 19217 & 19217 \\
\hline
\end{tabular}


Panel B: Matched Sample

\begin{tabular}{|c|c|c|c|c|c|c|}
\hline \multirow[b]{2}{*}{ Variable } & \multicolumn{4}{|c|}{ OLS } & \multirow{2}{*}{$\begin{array}{c}\text { Tobit } \\
\log (\text { Ext. Fin.Amount) }\end{array}$} & \multirow{2}{*}{$\frac{\text { Probit }}{\text { Ext. Fin. Transaction }}$} \\
\hline & Log(Ext. Fin.Amount) & Ext. Fin. Transaction & Log(Ext. Fin.Amount) & Ext. Fin. Transaction & & \\
\hline Private & $\begin{array}{c}-0.2542^{* * *} \\
(0.0376)\end{array}$ & $\begin{array}{c}-0.1032 * * * \\
(0.0134)\end{array}$ & $\begin{array}{c}-0.2521^{* * *} \\
(0.0374)\end{array}$ & $\begin{array}{c}-0.1026^{* * *} \\
(0.0139)\end{array}$ & $\begin{array}{c}-3.4814 * * * \\
(0.6577)\end{array}$ & $\begin{array}{c}-0.9102^{* * *} \\
(0.1454)\end{array}$ \\
\hline NCD Approval & $\begin{array}{c}0.0954^{* * *} \\
(0.0238)\end{array}$ & $\begin{array}{c}0.0503^{* * *} \\
(0.0087)\end{array}$ & $\begin{array}{c}0.1675^{* * *} \\
(0.0380)\end{array}$ & $\begin{array}{c}0.0910^{* * *} \\
(0.0148)\end{array}$ & $\begin{array}{c}1.1090^{* * * *} \\
(0.1903)\end{array}$ & $\begin{array}{c}0.3606^{* * * *} \\
(0.0573)\end{array}$ \\
\hline Private*(NCD approval) & $\begin{array}{c}-0.0888^{* * *} \\
(0.0243)\end{array}$ & $\begin{array}{c}-0.0456^{* * *} \\
(0.0082)\end{array}$ & $\begin{array}{c}-0.0980^{* * *} \\
(0.0318)\end{array}$ & $\begin{array}{c}-0.0501^{* * *} \\
(0.0110)\end{array}$ & $\begin{array}{c}-0.3267^{*} \\
(0.1920)\end{array}$ & $\begin{array}{c}-0.1217^{* *} \\
(0.0478)\end{array}$ \\
\hline Log(products per year) & $\begin{array}{c}0.1420^{* *} \\
(0.0562)\end{array}$ & $\begin{array}{c}0.0331^{* *} \\
(0.0154)\end{array}$ & $\begin{array}{c}0.1026 \\
(0.1305)\end{array}$ & $\begin{array}{c}0.0451 \\
(0.0412)\end{array}$ & $\begin{array}{c}1.1356 \\
(0.8592)\end{array}$ & $\begin{array}{c}0.3012 \\
(0.2243)\end{array}$ \\
\hline Age & $\begin{array}{c}-0.0048^{* * *} \\
(0.0012)\end{array}$ & $\begin{array}{c}-0.0019^{* * *} \\
(0.0005)\end{array}$ & $\begin{array}{c}-0.0033^{* *} \\
(0.0014)\end{array}$ & $\begin{array}{c}-0.0012^{* * *} \\
(0.0005)\end{array}$ & $\begin{array}{c}-0.0923^{* * *} \\
(0.0354)\end{array}$ & $\begin{array}{c}-0.0229^{* * *} \\
(0.0077)\end{array}$ \\
\hline Log(sales) & $\begin{array}{c}0.0419^{* *} \\
(0.0166)\end{array}$ & $\begin{array}{c}0.0098 \\
(0.0077)\end{array}$ & $\begin{array}{c}0.0529 * * * \\
(0.0184)\end{array}$ & $\begin{array}{c}0.0208^{* * *} \\
(0.0072)\end{array}$ & $\begin{array}{c}0.6799 * * * \\
(0.1918)\end{array}$ & $\begin{array}{c}0.1735^{* * * *} \\
(0.0486)\end{array}$ \\
\hline (NCD approval)* $\log ($ products per year) & & & $\begin{array}{c}0.0139 \\
(0.0461)\end{array}$ & $\begin{array}{c}-0.0038 \\
(0.0129)\end{array}$ & $\begin{array}{c}-0.1302 \\
(0.2294)\end{array}$ & $\begin{array}{l}-0.0429 \\
(0.0613)\end{array}$ \\
\hline (NCD approval)*Age & & & $\begin{array}{l}-0.0016^{*} \\
(0.0010)\end{array}$ & $\begin{array}{c}-0.0006^{* *} \\
(0.0003)\end{array}$ & $\begin{array}{c}0.0011 \\
(0.0069)\end{array}$ & $\begin{array}{l}-0.0008 \\
(0.0018)\end{array}$ \\
\hline (NCD approval)*Log(sales) & & & $\begin{array}{c}-0.0183^{* *} \\
(0.0085)\end{array}$ & $\begin{array}{c}-0.0133 * * * \\
(0.0032)\end{array}$ & $\begin{array}{c}-0.2431^{* * *} \\
(0.0658)\end{array}$ & $\begin{array}{c}-0.0749 * * * \\
(0.0167)\end{array}$ \\
\hline Year Fixed Effects & Yes & Yes & Yes & Yes & Yes & Yes \\
\hline Product Category Cluster & Yes & Yes & Yes & Yes & Yes & Yes \\
\hline R-squared & 0.088 & 0.099 & 0.093 & 0.11 & 0.11 & 0.17 \\
\hline $\mathbf{N}$ & 2428 & 2428 & 2428 & 2428 & 2428 & 2428 \\
\hline
\end{tabular}




\section{Table 6}

\section{Within Firm External Financing Sensitivity}

This table presents linear regressions examining the within-firm determinants of external financing transactions and amounts using firm fixed effects. The first 2 columns use the full sample and the third and fourth columns use a subsample of matched firms. Given that the goal is to exploit within-firm variation, we do not use the firm-year matched sample we utilize in previous analysis. Instead, we only consider Public firms that operate during the 13 years of the sample, and match them to private firms that also operate for all 13 years, using as matching characteristics firms' sales, firms' age and number of products introduced in 1998. We lose some public firms as there were no private firms with common support in the distribution. Our final sample consists of 63 matched pairs that operate through the whole sample period. The control variables included in the regression, but not shown in table, are log(products per year), and the interactions of NCD approvals with log(products per year), age and log(sales). Significant at: $* 10 \%, * * 5 \%$ and $* * * 1 \%$. Standard errors are adjusted for heteroscedasticity and clusters at the product category level.

\begin{tabular}{|c|c|c|c|c|}
\hline \multirow[b]{2}{*}{ Variable } & \multicolumn{2}{|l|}{ Full Sample } & \multicolumn{2}{|c|}{ Sample Matched on Initial Observation } \\
\hline & Log(Ext. Fin.Amount) & Ext. Fin. Transaction & Log(Ext. Fin.Amount) & Ext. Fin. Transaction \\
\hline Private & $\begin{array}{l}-0.5816^{*} \\
(0.2844)\end{array}$ & $\begin{array}{l}-0.1107 \\
(0.1308)\end{array}$ & & \\
\hline NCD Approval & $\begin{array}{c}0.1012 * * * \\
(0.0257)\end{array}$ & $\begin{array}{c}0.0541^{* * *} \\
(0.0147)\end{array}$ & $\begin{array}{c}0.2083^{* * *} \\
(0.0398)\end{array}$ & $\begin{array}{c}0.0589^{* * *} \\
(0.0118)\end{array}$ \\
\hline Private*(NCD approval) $^{*}$ & $\begin{array}{c}-0.0638^{* *} \\
(0.0272)\end{array}$ & $\begin{array}{c}-0.0385^{* *} \\
(0.0151)\end{array}$ & $\begin{array}{c}-0.0518 * * * \\
(0.0159)\end{array}$ & $\begin{array}{c}-0.0196^{* * *} \\
(0.0057)\end{array}$ \\
\hline Controls & Yes & Yes & Yes & Yes \\
\hline Firm Fixed Effects & Yes & Yes & Yes & Yes \\
\hline Year Fixed Effects & Yes & Yes & Yes & Yes \\
\hline Product Category Cluster & Yes & Yes & Yes & Yes \\
\hline R-squared (within) & 0.0177 & 0.0706 & 0.0418 & 0.0286 \\
\hline N & 19217 & 19217 & 1638 & 1638 \\
\hline
\end{tabular}




\section{Table 7}

\section{Economic Effects}

This table shows the economic effect of NCD approvals for private and public firms. We consider the economic effect of an NCD approval for three cases: first, the amount of external funds raised; second, the amount raised conditional on having an external financing transaction in a year; and third, the probability of raising external funds in a year. The estimates presented are obtained using the coefficient estimates from the base case regressions (Table 5, Panel A). The first and the third effects are obtained from the OLS regressions, the second effect is computed from the Tobit regression. Other specifications yield similar results. Significant at: $* 10 \%, * * 5 \%$ and $* * * 1 \%$.

Economic Effect of a NCD approval on External Financing

\begin{tabular}{cccc}
\hline & Private & Public & Difference \\
\hline $\begin{array}{c}\text { External funds increase } \\
\text { (unconditionally) by: }\end{array}$ & $1.6 \% *$ & $10 \% * * *$ & $8.4 \% * * *$ \\
$\begin{array}{c}\text { Conditional on having an external } \\
\text { financing transaction, external } \\
\text { funds increase by: }\end{array}$ & $4.2 \% * * *$ & $10.2 \% * * *$ & $6 \% * * *$ \\
$\begin{array}{c}\text { Probability of external financing } \\
\text { increases by: }\end{array}$ & $0.6 \% * *$ & $4.2 \% * * *$ & $3.6 \% * * *$ \\
\hline
\end{tabular}




\section{Table 8}

\section{Timing of External Financing}

This table presents linear regressions with firm fixed effects, redefining NCD approvals as 1 period shocks. Panel A shows the results for a falsification (placebo) test redefining the NCD approval variable as the year before actual NCD approvals take place (i.e., the NCD Approval variable takes a value of 1 the year prior to NCD approval, and 0 otherwise), Panel B shows the results for the NCD approval year, and Panels C-F show the results for 1 to 4 years after an NCD approval. In column one, the dependent variable is the logarithm of external financing amount in the years in which external financing was raised and zero otherwise. In column two, the dependent variable is an indicator variable that equals one if the firm raises external capital in a given year and zero otherwise. The control variables included in the regression, but not shown in table, are log(products per year), and the interactions of NCD approvals with $\log$ (products per year), age and $\log ($ sales). Significant at: $* 10 \%, * * 5 \%$ and $* * * 1 \%$. Standard errors are adjusted for heteroscedasticity and clusters at the product category level.

\begin{tabular}{|c|c|c|c|c|c|}
\hline Variable & Log(Ext. Fin.Amount) & Ext. Fin. Transaction & Variable & Log(Ext. Fin.Amount) & Ext. Fin. Transaction \\
\hline Panel A: 1 year before approval $(\mathrm{t}-1)$ & & & Panel D: 2 years after approval $(t+2)$ & & \\
\hline Private & $\begin{array}{c}-0.6713^{* *} \\
(0.2712)\end{array}$ & $\begin{array}{l}-0.1655 \\
(0.1340)\end{array}$ & Private & $\begin{array}{c}-0.6532 * * \\
(0.2680)\end{array}$ & $\begin{array}{l}-0.1594 \\
(0.1335)\end{array}$ \\
\hline NCD Approval Dummy (t-1) & $\begin{array}{c}0.0199 \\
(0.0883)\end{array}$ & $\begin{array}{l}-0.0005 \\
(0.0301)\end{array}$ & NCD Approval Dummy (t+2) & $\begin{array}{c}0.1989 * * * \\
(0.0499)\end{array}$ & $\begin{array}{c}0.0612 \\
(0.0359)\end{array}$ \\
\hline Private*(NCD Approval Dummy (t-1)) & $\begin{array}{l}-0.0147 \\
(0.0854)\end{array}$ & $\begin{array}{l}-0.0064 \\
(0.0268)\end{array}$ & Private*(NCD Approval Dummy $(t+2))$ & $\begin{array}{c}-0.2216^{* * *} \\
(0.0536)\end{array}$ & $\begin{array}{l}-0.0702 * \\
(0.0335)\end{array}$ \\
\hline R-squared (within) & 0.0151 & 0.0075 & R-squared (within) & 0.0152 & 0.0080 \\
\hline Panel B: Approval on year $t$ & & & Panel E: 3 years after approval $(t+3)$ & & \\
\hline Private & $\begin{array}{c}-0.6671^{* *} \\
(0.2693)\end{array}$ & $\begin{array}{l}-0.1623 \\
(0.1320)\end{array}$ & Private & $\begin{array}{c}-0.6638^{* *} \\
(0.2745)\end{array}$ & $\begin{array}{l}-0.1642 \\
(0.1364)\end{array}$ \\
\hline NCD Approval Dummy (t) & $\begin{array}{c}0.1593^{* *} \\
(0.0596)\end{array}$ & $\begin{array}{c}0.0712^{* * *} \\
(0.0209)\end{array}$ & NCD Approval Dummy (t+3) & $\begin{array}{c}0.0768 \\
(0.1208)\end{array}$ & $\begin{array}{c}0.0284 \\
(0.0453)\end{array}$ \\
\hline Private*(NCD Approval Dummy (t)) & $\begin{array}{c}-0.1379 * * \\
(0.0594)\end{array}$ & $\begin{array}{c}-0.0653^{* * *} \\
(0.0224)\end{array}$ & Private*(NCD Approval Dummy (t+3)) & $\begin{array}{l}-0.0818 \\
(0.1031)\end{array}$ & $\begin{array}{l}-0.0194 \\
(0.0417)\end{array}$ \\
\hline R-squared (within) & 0.0144 & 0.008 & R-squared (within) & 0.0142 & 0.0072 \\
\hline Panel $C: 1$ year after approval $(t+1)$ & & & Panel F: 4 years after approval $(t+4)$ & & \\
\hline Private & $\begin{array}{c}-0.6646^{* *} \\
(0.2660)\end{array}$ & $\begin{array}{l}-0.1638 \\
(0.1317)\end{array}$ & & $(0.2788)$ & $(0.1341)$ \\
\hline NCD Approval Dummy (t+1) & $\begin{array}{c}0.2162 \\
(0.1352)\end{array}$ & $\begin{array}{c}0.0550 \\
(0.0368)\end{array}$ & NCD Approval Dummy (t+4) & $\begin{array}{l}-0.0872 \\
(0.0863)\end{array}$ & $\begin{array}{c}0.0198 \\
(0.0461)\end{array}$ \\
\hline Private*(NCD Approval Dummy (t+1)) & $\begin{array}{l}-0.2173 \\
(0.1594)\end{array}$ & $\begin{array}{l}-0.0568 \\
(0.0447)\end{array}$ & Private*(NCD Approval Dummy (t+4)) & $\begin{array}{c}0.1161 \\
(0.0817)\end{array}$ & $\begin{array}{l}-0.0027 \\
(0.0391)\end{array}$ \\
\hline R-squared (within) & 0.015 & 0.0076 & R-squared (within) & 0.0142 & 0.0072 \\
\hline & & $\begin{array}{c}\text { N } \\
\text { Controls } \\
\text { Firm Fixed Effects } \\
\text { Year Fixed Effects } \\
\text { Product Category Cluster }\end{array}$ & $\begin{array}{l}19217 \\
\text { Yes } \\
\text { Yes } \\
\text { Yes } \\
\text { Yes }\end{array}$ & & \\
\hline
\end{tabular}




\section{Table 9}

\section{Multinomial Logit Estimation of Transaction Types Driving the Results}

This table presents multinomial logit regressions examining different types of financing decisions for both privately held and publicly listed companies. Panel A presents a multinomial logit of financing decisions for privately held companies, where the default option is not obtaining external financing. Panel B presents a multinomial logit of financing decisions for publicly listed companies, where the default option is not obtaining external financing. The changes in probabilities following a NCD approval are shown at the bottom of each panel. Significant at: $* 10 \%, * * 5 \%$ and $* * * 1 \%$.

Panel A: Private firms

Default Option: No External Financing

\begin{tabular}{|c|c|c|c|c|}
\hline Variable & Bank Loan & Venture Capital & Growth Capital & IPO \\
\hline NCD Approval & $\begin{array}{l}-0.0467 \\
(0.3332)\end{array}$ & $\begin{array}{c}0.2231^{* * *} \\
(0.0418)\end{array}$ & $\begin{array}{c}0.1728^{* *} \\
(0.0691)\end{array}$ & $\begin{array}{l}0.3370^{* *} \\
(0.1543)\end{array}$ \\
\hline Log(products per year) & $\begin{array}{c}0.1491 \\
(0.3563)\end{array}$ & $\begin{array}{c}0.2911 * * * \\
(0.1023)\end{array}$ & $\begin{array}{l}0.3694 * * \\
(0.1468)\end{array}$ & $\begin{array}{l}0.5071^{*} \\
(0.2658)\end{array}$ \\
\hline Age & $\begin{array}{l}-0.0059 \\
(0.0110)\end{array}$ & $\begin{array}{c}-0.1715 * * * \\
(0.0125)\end{array}$ & $\begin{array}{c}-0.0834 * * * \\
(0.0136)\end{array}$ & $\begin{array}{r}-0.0480^{* *} \\
(0.0222)\end{array}$ \\
\hline $\log ($ sales $)$ & $\begin{array}{c}1.2285 * * * \\
(0.2018)\end{array}$ & $\begin{array}{c}0.4329 * * * \\
(0.0496)\end{array}$ & $\begin{array}{c}0.6315^{* * * *} \\
(0.0748)\end{array}$ & $\begin{array}{r}0.6471^{* * *} \\
(0.1588)\end{array}$ \\
\hline $\begin{array}{c}\text { Year Fixed Effects } \\
\mathbf{N}\end{array}$ & \multicolumn{4}{|c|}{17938} \\
\hline Unconditional Probability & $0.1 \%$ & $1.7 \%$ & $0.6 \%$ & $0.1 \%$ \\
\hline Marginal Effect (NCD Approval) & $0.00 \%$ & $0.08 \% * * *$ & $0.05 \% * *$ & $0.00 \%$ \\
\hline $\begin{array}{c}\Delta \text { Probability following } \\
\text { NCD approval }\end{array}$ & $0.0 \%$ & $4.9 \%$ & $8.3 \%$ & $0.0 \%$ \\
\hline
\end{tabular}

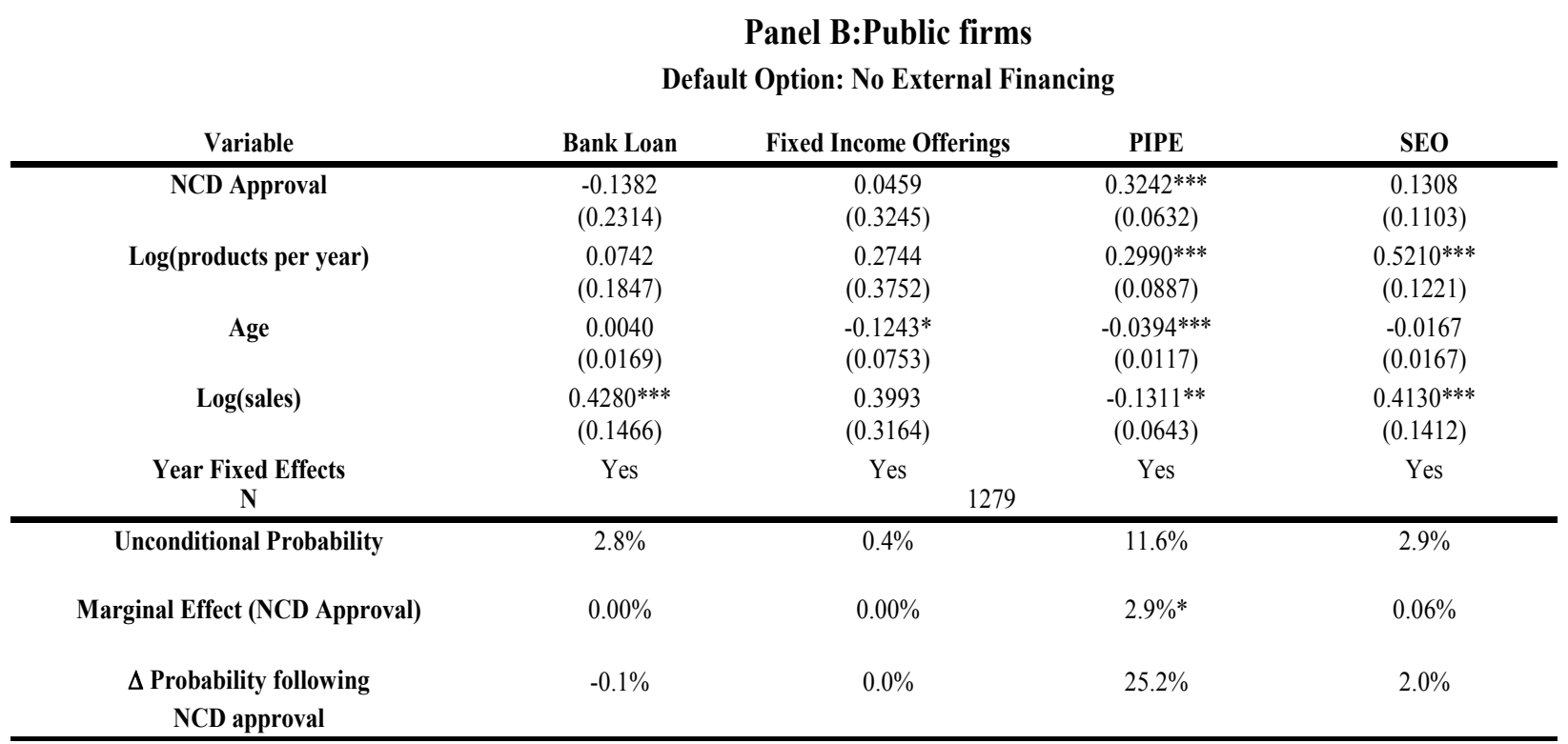




\section{Table 10}

\section{Multinomial Logit Estimation for Acquisitions}

This table presents multinomial logit regressions examining acquisition activity for both privately held (Panel A) and publicly listed companies (Panel B). We examine whether firms are more likely to be acquired or to acquire other firms according to the covariates included in the estimations. The default option for both panels is that the firm is not involved in acquisitions. The changes in probabilities following a NCD approval are shown at the bottom of each panel. Significant at: $* 10 \%, * * 5 \%$ and $* * * 1 \%$.

\section{Panel A: Private firms}

Default Option: No Acquisition Activity

\begin{tabular}{ccc} 
Variable & Acquired & Acquiring \\
\hline NCD Approval & -0.0146 & 0.1067 \\
& $(0.0587)$ & $(0.0748)$ \\
Log(products per year) & $0.4248^{* * *}$ & 0.2049 \\
& $(0.1081)$ & $(0.1424)$ \\
Age & $-0.0121^{* * *}$ & $-0.0172^{* * *}$ \\
& $(0.0044)$ & $(0.0055)$ \\
Log(sales) & $0.6025^{* * *}$ & $0.8660^{* * *}$ \\
& $(0.0525)$ & $(0.0658)$ \\
Year Fixed Effects & Yes & Yes \\
N & & $1 / 938$ \\
\hline Unconditional Probability & $1.2 \%$ & $0.7 \%$ \\
Marginal Effect (NCD Approval) & $0.00 \%$ & $0.04 \%$ \\
D Probabillty tollowing & $-0.43 \%$ & $5.57 \%$ \\
NCD approval & & \\
\hline
\end{tabular}

\section{Panel B: Public firms}

Default Option: No Acquisition Activity

\begin{tabular}{ccc} 
Variable & Acquired & Acquiring \\
\hline NCD Approval & 0.1978 & -0.1424 \\
& $(0.1421)$ & $(0.1006)$ \\
Log(products per year) & -0.1727 & $0.1788^{*}$ \\
& $(0.2259)$ & $(0.1018)$ \\
Age & -0.0267 & 0.0070 \\
& $(0.0222)$ & $(0.0099)$ \\
Log(sales) & $0.3427 * *$ & $0.1674^{* *}$ \\
& $(0.1468)$ & $(0.0800)$ \\
Year Fixed Effects & Yes & Yes \\
N & \multicolumn{2}{c}{$12 / 4$} \\
\hline Unconditional Probability & $1.7 \%$ & $6.4 \%$ \\
Marginal Effect (NCD Approval) & $0.04 \%$ & $-0.76 \%$ \\
Probabılıty tollowing & $2.26 \%$ & $-11.78 \%$ \\
NCD approval & \multicolumn{2}{c}{} \\
\hline
\end{tabular}




\section{Table 11}

\section{Product Introduction Count Regressions}

This table presents count regressions examining cumulative product introductions from year $t$ to $t+x$, where $\mathrm{x}=\{1,2,3,4\}$, using a negative binomial regression, as the dependent variable is a count variable with overdispersion (i.e., the variance is higher than the mean). The marginal effects of NCD approvals on product introductions of private and public firms, as well as their differences, are shown at the bottom of the table. Significant at: *10\%, **5\% and $* * * 1 \%$. Standard errors are adjusted for heteroscedasticity and clusters at the product category level.

\begin{tabular}{|c|c|c|c|c|}
\hline Variable & Prod. Intro. $(t-t+1)$ & Prod. Intro. $(t-t+2)$ & Prod. Intro. $(t-t+3)$ & Prod. Intro. $(t-t+4)$ \\
\hline Private & $\begin{array}{c}-0.7397 * * * \\
(0.1557)\end{array}$ & $\begin{array}{c}-0.7674 * * * \\
(0.1616)\end{array}$ & $\begin{array}{c}-0.7946 * * * \\
(0.1617)\end{array}$ & $\begin{array}{c}-0.8199 * * * \\
(0.1660)\end{array}$ \\
\hline NCD Approval & $\begin{array}{c}0.2834 * * * \\
(0.0965)\end{array}$ & $\begin{array}{c}0.2938 * * * \\
(0.1115)\end{array}$ & $\begin{array}{l}0.3165 * * * \\
(0.1192)\end{array}$ & $\begin{array}{l}0.3502 * * * \\
(0.1268)\end{array}$ \\
\hline Private*(NCD approval) & $\begin{array}{c}-0.2329^{*} \\
(0.1280)\end{array}$ & $\begin{array}{c}-0.2384 * \\
(0.1440)\end{array}$ & $\begin{array}{l}-0.2529 \\
(0.1557)\end{array}$ & $\begin{array}{c}-0.2772 * \\
(0.1625)\end{array}$ \\
\hline Age & $\begin{array}{c}-0.0191 * * * \\
(0.0063)\end{array}$ & $\begin{array}{c}-0.0187 * * * \\
(0.0062)\end{array}$ & $\begin{array}{c}-0.0179 * * * \\
(0.0063)\end{array}$ & $\begin{array}{c}-0.0171 * * * \\
(0.0065)\end{array}$ \\
\hline Log(sales) & $\begin{array}{c}0.4513 * * * \\
(0.0630)\end{array}$ & $\begin{array}{l}0.4558 * * * \\
(0.0656)\end{array}$ & $\begin{array}{l}0.4545 * * * \\
(0.0657)\end{array}$ & $\begin{array}{l}0.4533 * * * \\
(0.0664)\end{array}$ \\
\hline $\begin{array}{c}\text { Year Fixed Effects } \\
\text { Product Category Cluster } \\
\text { N }\end{array}$ & $\begin{array}{c}\text { Yes } \\
\text { Yes } \\
17397\end{array}$ & $\begin{array}{c}\text { Yes } \\
\text { Yes } \\
15598\end{array}$ & $\begin{array}{c}\text { Yes } \\
\text { Yes } \\
13828\end{array}$ & $\begin{array}{c}\text { Yes } \\
\text { Yes } \\
12093\end{array}$ \\
\hline $\begin{array}{l}\text { NCD Approval Marginal } \\
\text { Effect for Private Firms }\end{array}$ & 0.02 & 0.05 & 0.09 & 0.13 \\
\hline $\begin{array}{l}\text { NCD Approval Marginal } \\
\text { Effect for Public Firms }\end{array}$ & $0.14^{* * *}$ & $0.29 * * *$ & $0.47 * * *$ & $0.68^{* * *}$ \\
\hline $\begin{array}{c}\text { NCD Differential Effect } \\
\text { (Public vs.Private) }\end{array}$ & $0.12 * *$ & $0.24 *$ & $0.38 *$ & $0.55^{*}$ \\
\hline
\end{tabular}


Table 12

\section{Evidence of Firm Selection into Public/Private Status}

Panel A shows the average of products introduced per year for the companies that underwent an IPO during the sample period, in the four years prior to their IPO ("Going Public" firms). There are 22 firms that underwent an IPO in our data between 1998-2010, but given that we study their product introductions in the 4 years prior to the IPO, we restrict our attention to the 17 firms that went public from 2002 to 2010 . We compare these companies to a sample of private firms that choose to stay private, matched on their age and calendar year using propensity score matching ("Staying Private" firms). The difference in products introduced per year is shown in the right column. Panel B shows the mean sales per employee for publicly traded firms and a matched set of privately held firms (2011 is the only year where sales and employee information is available in the data; the matching is based on age, using propensity score matching). Significant at: $* 10 \%, * * 5 \%$ and $* * * 1 \%$.

Panel A: Products Introduced in a Year

\begin{tabular}{cccc}
\hline & Going Public & Staying Private & Difference \\
\hline 4 years to IPO & 0.30 & 0.24 & 0.06 \\
3 years to IPO & 0.47 & 0.53 & -0.06 \\
2 years to IPO & 0.59 & 0.06 & $0.53^{* *}$ \\
1 year to IPO & 0.94 & 0.23 & $0.71^{* *}$ \\
\hline Mean 1-4 years prior to IPO & 0.57 & 0.26 & $0.31^{*}$ \\
\hline
\end{tabular}

Panel B: Cross-Sectional Productivity Differences

\begin{tabular}{cccc}
\hline & Public & Private & Difference \\
\hline Sales/Employees & $\$ 191,964$ & $\$ 116,326$ & $\$ 75,638^{* * *}$ \\
\hline
\end{tabular}




\section{Appendix A}

\section{Examples of the PIPE transactions that drive the results}

Deal \#: IQTR2387540. Cardiac Pathways Corp. (Nasdaq: CPWY) announced a private placement of 40,000 shares of Series B convertible preferred stock at a purchase price of $\$ 1,000$ per share for aggregate gross proceeds of $\$ 40$ million on May 20, 1999. The financing will be led by new investors BankAmerica Ventures and Morgan Stanley Venture Partners, and Trellis Health Ventures, and other existing investors also participated in the round. Each shares of Series B preferred stock will be convertible into 200 shares of common stock. The holders of Series B will be entitled to receive cumulative dividend at $11 \%$ of the purchase price per share per annum and will vote on all matters on as converted to common stock basis. The Series B stock will be redeemable after May 31, 2004 at the request of the majority shareholders and the approval by the company. As a part of the financing, Mark J. Brooks, Managing Director of BA Venture Partners, and M. Fazle Husain, Principal of Morgan Stanley Venture Partners, will join Cardiac Pathways' board of directors. Julia L. Davidson of Cooley Godward LLP and John Bick of Davis Polk and Wardwell acted as legal advisors to Morgan Stanley Venture Partners and BankAmerica Ventures. Chris F. Fennell of Wilson Sonsini Goodrich \& Rosati served as the legal advisor to Cardiac Pathways Corp.

Deal \#: IQTR112649608. CardioComm Solutions Inc. (VSE: CCG) announced a private placement of 646,667 units at a price of CAD 0.15 per unit for gross proceeds of CAD 0.10 million on March 29, 1999. Each unit consists of one common share of the company and one non-transferable share purchase warrant exercisable for a period of two years. Each warrant entitles the holder to purchase one further common share of the company at a price of CAD 0.15 during the first year and CAD 0.18 during the second year. The warrants will mature on March 29, 2001.

Deal \#: IQTR7282288. Criticare Systems, Inc. (NASDAQ-NMS: CXIM) announced a private placement of $1,786,273$ shares of common stock at $\$ 2.25$ per share for gross proceeds of $\$ 4.02$ million on October 17 , 2000. The round included participation from new investor Oxford Bioscience Partners with an investment $\$ 4$ million through its funds Oxford Bioscience Partners III, L.P and Mrna Fund L.P. As part of the round Jeff Barnes, General Partner at Oxford, will join company's board of directors.

Deal \#: IQTR7129416. On December 23, 2003, HealtheTech, Inc. (Nasdaq: HETC) announced that it has closed \$11.7 million in financing commitments from current and new investors. The company sold $15,394,737$ shares of common stock at a negotiated price of $\$ 0.76$ per share. The company also issued warrants to purchase approximately 10,776,316 million shares of common stock at an exercise price of $\$ 0.76$ per share. Kodial Capital was the lead investor in the transaction. Other investors included Sherbrooke Capital Health and Wellness, LP, New England Partners Capital, LP, JDS Capital Management, Inc., CCM Master Qualified Fund, Ltd. and individual investors.

Deal \#: IQTR23440373. Medwave Inc. (NasdaqSC: MDWV) announced that it has raised \$1,154,672 in the first tranche of a private placement of up to approximately $\$ 7$ million of units on March 20,2001. The company issued 181,125 units at a price of $\$ 6.375$ per unit. Each unit consists of one share of common stock and one warrant to purchase one and one-half shares of common stock. The warrants become exercisable six months after the date of issuance at an exercise price of $\$ 6.425$ per share. Also, included with each unit is a look-back right entitling the investor to receive, for no additional consideration, a number of additional shares if the company's future gross revenue does not meet certain targets. 